\title{
Corporate reputation past and future: a review and integration of existing literature and a framework for future research
}

Article

Accepted Version

Money, K., Saraeva, A., Garnelo-Gomez, I., Pain, S. and Hillenbrand, C. (2017) Corporate reputation past and future: a review and integration of existing literature and a framework for future research. Corporate Reputation Review, 20 (3-4). pp. 193-211. ISSN 1479-1889 doi: https://doi.org/10.1057/s41299017-0034-3 Available at https://centaur.reading.ac.uk/72946/

It is advisable to refer to the publisher's version if you intend to cite from the work. See Guidance on citing.

To link to this article DOI: http://dx.doi.org/10.1057/s41299-017-0034-3

Publisher: Palgrave Macmillan

All outputs in CentAUR are protected by Intellectual Property Rights law, including copyright law. Copyright and IPR is retained by the creators or other copyright holders. Terms and conditions for use of this material are defined in the End User Agreement.

www.reading.ac.uk/centaur 
Central Archive at the University of Reading

Reading's research outputs online 
Corporate Reputation Past and Future:

A Review and Integration of Existing Literature and a Framework for Future Research Kevin Money, Anastasiya Saraeva, Irene Garnelo-Gomez, Stephen Pain and Carola Hillenbrand

\title{
Accepted for publication by Corporate Reputation Review
}

\begin{abstract}
The concept of corporate reputation is steadily growing in interest among management researchers and practitioners. In this article, we trace key milestones in the development of reputation literature over the past six decades to suggest important research gaps as well as to provide contextual background for a subsequent integration of approaches and future outlook. In particular we explore the need for better categorised outcomes; a wider range of causes; and a deeper understanding of contingencies and moderators to advance the field beyond its current state while also taking account of developments in the macro business environment. The article concludes by presenting a novel reputation framework that integrates insights from reputation theory and studies, outlines gaps in knowledge and offers directions for future research.
\end{abstract}




\section{Introduction}

Corporate reputation (CR) and its related terms and concepts are receiving considerable attention in management theory and practice, as evidenced in 20 years of Corporate Reputation Review articles and celebrated in this anniversary issue. Despite growing interest, however, CR research is often criticised as being ambiguous, loosely scattered across various disciplines and difficult to conduct due to the intangible nature of the concept (Herbig and Milewicz, 1993; Lewellyn, 2002; Deephouse and Carter, 2005; Barnett et al, 2006; Brown et al, 2006). As CR is nevertheless widely seen to hold much promise for the future of management theory and practice, we dedicate this article to a review and integration of CR studies with the hope that our work may contribute towards more clarity in the field and appealing avenues for future research. As such this article aims to make three key contributions.

First, a review of the existing reputation literature is provided in Section 1 of this article with the aim of summarising key milestones over the past six decades. The review describes key streams of CR research and important research gaps while also indicating common themes and merging viewpoints across time periods and from different perspectives. Hence, Section 1 is organised in three subsections, summarising CR literature in the time periods from 1940-1990, 1990-2006 and 2006-2017(present). These periods are chosen as they offer a useful way to highlight important conceptual developments over time and offer interesting insights regarding the growth of the field. Any division of an academic field in separate time periods is imposed and there will naturally be overlap and crossover between time periods, publication dates and conceptual developments. The chosen time periods in 
this article should thus be seen as an attempt to introduce a structure that is useful for the purpose of this review, rather than proposed to be definite by nature.

Insights into how CR research evolves over these periods extend previous reviews by scholars such as Walker (2010) and Lange et al. (2011) as they relate, for example, to whether a commonly chosen level of analysis in CR studies is the organisation or the individual; whether CR is conceptualised from a strategic or relational perspective; how CR is thought to be best measured; if and how the idea of stakeholders is integrated in CR studies; and how CR research is linked to other academic areas, disciplines and management theories. Interestingly, the review indicates that research is progressing from a focus on measuring CR as a 'standalone' concept (and if linked to other areas then mostly to the financial performance of organisations) to research aiming to embed CR into a more comprehensive analysis of causes and outcomes as a way to understand the development and wider purpose of CR, i.e. its antecedents and consequences. As such, this article also differs from previous work as it outlines that much is still unknown with regard to the underlying mechanisms by which CR develops in different circumstances, such as the contingencies and moderators at play, how the concept links to key developments and insights in related disciplines, and how changes in the business environment can best be embedded in future research.

As a second contribution of this article, therefore, Section 2 discusses key gaps in current knowledge and suggests opportunities for future research as relating particularly to the need for better categorised outcomes, a wider range of causes, and a deeper understanding of contingencies and moderators. Importantly, Section 2 takes account of developments in both business and society, and links the need for future CR research to macro trends such as 
disparity of power between governments and business; population growth, urbanisation and climate change; and instantaneous connectivity and global information flow.

Building on the contextual background provided in Section 1, and building on the discussion of research gaps and current business trends in Section 2, the article finishes by offering an integration of CR themes and approaches in Section 3 by presenting a novel reputation framework and suggestions for future development of the field. The framework distinguishes between organisation-oriented and stakeholder-oriented levels of analysis and organises causes and outcomes of CR in a sequential manner with suggested themes, moderators and feedback loops as the third and final contribution of this article.

\section{Review of reputation literature}

The evolution of CR literature is displayed chronologically in Table 1, as a way of demonstrating the development of thinking over critical time periods.

[Table 1 about here]

The time periods 1940-1990, 1990-2006 and 2006-2017 are chosen in this article to represent important conceptual developments: from 1940-1990 CR is predominantly looked at in terms of assets and signalling power and is often conceptualised from a strategic perspective. This early stage of CR research is, in hindsight, sometimes referred to as unidirectional in that $\mathrm{CR}$ is seen to be managed 'from company to stakeholder' (Balmer, 1998) and, unsurprisingly, the level of analysis is often the organisation. From 1990-2006, a strategic/asset-based perspective on $\mathrm{CR}$ as well as a relational perspective gain momentum. The concept of stakeholders gets more integrated into CR literature, as scholars call for studies including the perspective of recipients/observers of $C R$, and as a consequence more studies from an individual level of analysis emerge. Importantly, a number of scholars 
propose ways of measuring $C R$ in this time period and attempts are made to place $C R$ into causal frameworks. From 2006 onwards both a strategic and relational approach to CR research continue to coexist and scholars in both camps call to increasingly study antecedents and consequences of CR as a way to determine causes and outcomes. Also, links are increasingly being made between CR and other academic theories and disciplines as scholars are looking for complexity as well as nuance and subtlety; and for integration of findings and knowledge. Recent literature also points to the need to better understand contingencies and underlying mechanisms of the development of $C R$ and to link $C R$ research more systematically to wider trends in the macro environment.

\subsection{Time period $1940-1990$}

Corporate reputation as an academic subject is suggested to originate from the public relations literature in the United States in the late 1940s (Barlow and Payne, 1949; Woodward and Roper, 1951; Christian 1959; Macleod, 1967; Weaver, 1988), when large US corporations were seen to express an interest in the views of local communities.

Interestingly, in this period MacLeod (1967) poses three critical questions that could be seen to describe the heart of much subsequent reputation research and are still relevant today: 'What is a company's reputation based on? How is it measured? How can a company use its reputation to specific advantage?' (p. 67).

Typically, at this early stage, CR is described as a strategic intangible asset that can contribute to current and future profitability and competitive advantage (Shrum and Wuthnow, 1988; Weigelt and Camerer, 1988; Cloninger, 1995). The mechanisms for success are often explained through the signals that CR sends about a company's attractiveness and capability (Milgrom and Roberts, 1986; Raihi-Belkaoui and Pavlik, 1991; Bagwell, 1992). 
Later often reviewed with reference to signal theory (Fombrun and Shanley, 1990; Turban and Greening, 1997; Basdeo et al, 2006), studies in these years therefore often focus on how, when and why good reputations may signal desired corporate benefits, e.g. competitive advantage, better applicants and financial performance (Shapiro, 1983; Freeman, 1984; Weigelt and Camerer, 1988; Dutton and Dukerich, 1991).

Given the early reliance of CR studies on strategic thinking and links to profitability, the conceptual developments by Shapiro (1983), Weigelt and Camerer (1988) and Fombrun and Shanley (1990) mark significant milestones in CR literature. Shapiro (1983) is among the first to offer theoretical and empirical evidence on the impact of CR on financial return and this work significantly influences later studies on the link between CR and financial performance (e.g. Cloninger, 1995; Hammond and Slocum, 1996; Roberts and Dowling, 1997; Miles and Covin, 2000; Kitchen and Laurence, 2003; Sebate and Puente, 2003; Carmeli and Tishler, 2004; Neville et al, 2005). Weigelt and Camerer (1988) enrich the debate through a focus on a set of corporate attributes that the authors suggest contribute towards CR development. Moving the field forward, Fombrun and Shanley (1990) then suggest a yet broader set of elements (from financial to emotional) relevant to CR. In doing so, the authors start to mark a transition in CR literature from a mainly strategic lens towards a relational and perceptionbased approach in the next time period, as they start to signal the perspective of external constituents as well as cognitive and emotive elements in the conceptualisation of CR.

\subsection{Time period $1990-2006$}

From the 1990s onwards, CR research spreads noticeably from the United States to Europe with more studies emerging, for example, from scholars in the UK (e.g. Bromley, 1993; Balmer, 1998; Macmillan et al, 2000, 2004), Germany (e.g. Wiedmann, 2002; Walsh and 
Wiedmann, 2004; Wiedmann and Buxel, 2005), Italy (e.g. Zattonni and Ravasi, 2000; Ravasi, 2002; Giabionetta, 2007) and the Netherlands (e.g. van Riel, 2002; Berens and van Riel, 2004; Maathuis et al, 2004).

While the earlier discussed stream of strategic CR research continues to thrive (Hall, 1992; Grunig, 1993; Yoon et al, 1993; Dollinger, 1997; Roberts and Dowling, 1997, 2002; Carmeli and Tishler, 2004), often now theorised on the resource-based view of the firm (Barney, 1991; Hall, 1992, 1993; Deephouse, 2000), an alternative perspective is starting to emerge in the literature that views CR as perception based (Wartick, 1992; Bromley, 1993; Fombrun, 1996; Chun, 2001; Mahon and Wartick, 2003; Dowling, 2004; MacMillan et al, 2004). At the time of the millennium, two distinct streams of CR research are clearly present: reputation as intangible asset, with research often conducted at the organisational level, (e.g. Roberts and Dowling, 1997, 2002; Pertick et al, 1999; Deephouse, 2000; Waddock, 2000) and reputation as stakeholder perceptions, with research often conducted at the individual level (e.g. Balmer, 1998; Bromley, 2001; Johnston, 2002; Makon and Wartick, 2002; Macmillan et al, 2004; Walsh and Wiedmann, 2004).

A contribution to define CR from a perceptual perspective is then provided by Wartick (1992) arguing that 'corporate reputation is the aggregation of a single stakeholder's perceptions of how well organisational responses are meeting the demands and expectations of many organisational stakeholders' (p. 34). A related definition is offered by Fombrun (1996), who sees reputation as 'a perceptual representation of a company's past actions and future prospects that describes the firm's overall appeal to all of its key constituents when compared with other leading rivals' (p. 72), which remains one of the most cited definitions in the literature (Dowling, 2016). 
Indeed, defining and differentiating CR is what many writers in the time period 1990-2006 aim to achieve. While early scholars hardly differentiate between the concepts of image, identity and reputation, and often use these terms interchangeably (Christian, 1959; MacLeod, 1967; Dunne, 1974), scholars in the 90s and early 2000s try to be more explicit (see for example Ettorre, 1996; Fombrun and van Riel, 1997; Nowak and Washburn, 2000; Davies et al, 2001; Pruzan, 2001). In an attempt to simplify the field, Brown et al (2006) - in a seminal work and similar to Cornelissen et al (2007) - refer to identity as internal associations about a company, which are held by its members (based on Albert and Whetten, 1985); to organisational image as internally held associations, which reflect how others view a company; and to CR as external individual stakeholders' views of the organisation.

Furthermore, measuring CR emerges as a key ambition of scholars in the time period 19902006. Measurement tools and framework are published, for example, by scholars such as Fombrun (1996), Davies et al (2003), Berens and Van Riel (2004) and MacMillan (2004). In an effort to categorise and summarise measurement tools, Money and Hillenbrand (2006) propose a reputation framework that integrates existing measurement models and differentiates between scales relating to causes, reputation and consequences of CR. Their framework builds on the seminal work by Rindova (2005) and Walsh and Wiedmann (2004) to integrate organisational and stakeholder-oriented approaches to CR with the use of wellestablished psychological theory, and is displayed in Figure 1.

[Figure 1 about here]

As evident in the development of CR measurement tools and CR definitions between 1990 and 2006, CR literature becomes increasingly intertwined with stakeholder research (e.g. 
Morgan and Hunt, 1994; O'Hair et al, 1995; Huang, 1998; Broom et al, 2000; Macmillan et al, 2000; Yang and Grunig, 2005). As such, CR scholars are often using exchange theory (Anderson and Weitz, 1992; Lambe et al, 2001) and relationship reciprocity (Gassenheimer et al, 1998; Wulf et al, 2001; Greenwood, 2007) as theoretical underpinnings of conceptual developments, and pay increasing attention to a two-way nature of company-stakeholder relationships, which corresponds with Freeman's (1984) original work on stakeholder theory, where he defines stakeholders as 'anyone who affects and is affected' by a company.

The shift to stakeholders and stakeholder perception in CR studies is furthermore accompanied by a shift to more research looking at the emotional, cognitive and behavioural elements of CR (Dutton and Dukerich, 1991; Bromley, 1993; Dutton et al, 1994; Balmer, 1997; Chun, 2005; Walsh et al, 2009). Corporate reputation studies thereby include both research with internal stakeholders (Dutton et al, 1994; Gioia and Thomas, 1996; Post and Griffin, 1997; Arnold et al, 2003) and external stakeholders (e.g. Goldberg and Hartwick, 1990; Bromley, 1993; Dowling, 1993; Vendelo, 1998; Davies et al, 2001). Scholars such as Bromley (1993) also increasingly call for research to include the outcome behaviours of stakeholders - a notion that will emerges further in the next and final time period discussed in this article.

\subsection{Time period $2006-2017$ (present)}

With the strategic/asset-based as well as the relational/perception-based approach to CR both well established by 2006, recent work often aims to better ground, legitimise and understand CR by linking it explicitly to management theories and other disciplines. 
From a strategic/asset-based perspective work is conducted, for example, by Srivoravilai et al (2011) utilising institutional theory (see also Rao, 1994; Staw and Epstein, 2000;

Deephouse and Carter, 2005; Foreman et al, 2012; Davies and Chun, 2015; Davies and Olmedo-Cifuentis, 2016; Deephouse et al, 2016); by Gardberg et al (2015) utilising signalling theory (see also Basdeo et al, 2006; Newburry, 2010; Walsh et al, 2015, 2017; Gardberg et al, 2017); by Mahon et al (2004) building on non-market strategy (see also Mahon and Wartick, 2003; Ghobadian et al, 2015; Liedong et al, 2015) and by Deephouse (2000) and others utilising resource-based theory (see also Roberts and Dowling, 2002; Shamsie, 2003; Carmeli and Tishler, 2004; Carter and Ruefli, 2006; Bergh et al, 2010). Furthermore, Carroll and McCombs (2003) bring agenda-setting theory to CR literature, and explore effects of media on CR development (see also Kiousis et al, 2007; Carroll, 2010; Besiou et al, 2013; Bantimaroudis and Zyglidopoulos, 2014; Lee et al, 2015).

From a relational/perception-based perspective, Wang and Berens (2015) use stakeholder theory (see also Cable and Graham, 2000; Kreiner and Ashforth, 2004; Deephouse, 2007; Bhattacharya et al, 2008; Freeman, 2010); and Money et al (2012) build on psychological approaches and relationship theories (see also MacMillan et al, 2004, 2005; Hosmer and Kiewitz, 2005; Rindova et al, 2005; Korschun et al, 2014; Walsh et al, 2017). Korschun (2015) draws on social identity theory and explores psychological contributors to stakeholder relationships (see also Helm, 2011, 2012; Ashforth et al, 2013; Korschun and Du, 2013; Beatty et al, 2016); Sjovall and Talk (2004) utilise attribution theory to understand how cognitive processes drive stakeholders to form perceptions of CR (see also Love and Kraatz, 2009, 2017; Mishina et al, 2012; Helm, 2013); and Ravasi (2016) utilises identity and identification theories (see also Whetten et al 2014; Ravasi and Canato, 2013). 
While scholars across CR camps (and utilising a variety of theoretical underpinnings) call for more nuanced CR research and better developed models, the authors of this article are particularly affiliated with the relational/perception-based view of $\mathrm{CR}$, and will thus focus on research gaps and future outlook particularly from that perspective in the rest of this article. While the authors warmly welcome a broadening of CR study beyond the relational view, a review and outlook analysis in that regard is better served by scholars who actively publish in this area.

Within the relational approach to CR research, much research from 2006 onwards focuses on a deep exploration of stakeholder perceptions, emotions, beliefs and thoughts (Money and Hillenbrand, 2006; Helm, 2011; Ponzi et al, 2011; Fombrun, 2012; Helm, 2013), often with the hope to shed light on a longstanding and worrying lacuna in CR research: why stakeholders often react unpredictably and differently to the same organisational stimuli (Bhattacharya et al, 2009; Walker, 2010; Mishina et al, 2012; Money et al, 2012; West et al, 2015). Hence one important stream of CR research from 2006 onwards addresses the underlying processes that underpin relationships and attitude development of individuals. However, while scholars are often interested in unpacking underlying (often psychological) mechanisms by which CR leads to stakeholder behaviour (Bhattacharya and Sen, 2004; Walker, 2010) the range of outcome behaviours explored in CR literature still remains limited.

Corporate reputation-related outcomes and benefits that are typically studied include, for example, stakeholder loyalty and commitment (Helm, 2007; Caruana and Ewing, 2010; Eberl, 2010; Bartikowski et al, 2011); purchase intentions among customers (e.g. Sen and Bhattacharya, 2001; Walsh et al, 2006; 2009; Carroll, 2009; Hong and Yang, 2009); 
intentions to invest or seek employment (e.g. Einwiller et al, 2010; Newburry, 2010; Ponzi et al, 2011); and advocacy or word of mouth (e.g. Hong and Yang, 2009; Cai et al, 2014; Change et al, 2015).

These stakeholder behaviours seem mostly focused on commercial benefit for companies, and questions are arising about a potentially wider range of outcomes related to CR that could be of interest to study. Money et al (2009), Shamma and Hassan (2009), Newbutty (2010), Ponzi et al (2011) and Garnelo-Gomez et al (2015), for example, call for research that links reputation to outcomes such as, sustainable consumption, employee wellbeing, and pride and happiness of communities. This will be discussed more fully in Section 2 . Related to the previous point, CR scholars also call for studies to better understand the causes of stakeholder perceptions and feelings (Ponzi et al, 2011; Fombrun, 2012). Fombrun (2012), for example, suggests three sources for reputation drivers as stakeholders' personal experiences, corporate initiatives and other communication/media. As such, CR scholars are advised to not operate in isolation but, rather, build on advances in the study of perceptions and emotions more widely. For example, a recent study exploring sustainable living (Money et al, 2016) utilises advances in the understanding of human motivation and, in particular, the work of Lawrence (2010) and Lawrence and Nohria (2002) as the lens through which the developments of perceptions and emotions related to sustainable behaviours are developed.

Again, this point will be further explored in Section 2, as the authors believe that understanding the causes of CR holds much promise: often, the starting point of such attempts is a deeper understanding of human nature, which does not presume humans are rational or logical in decision making, as many early management studies in this domain do. 
Rather, seemingly irrational behaviours such as unsustainable consumption patterns can be explained in terms of the broader impact of an imbalance in expression of human drives in Western society.

Finally, there is a strong call in recent CR studies to better understand the contingencies and moderators at play in CR research. Much recent work still looks at stakeholders as homogeneous groups, often assuming that stakeholders within functional silos (e.g. customers, employees, communities) respond and act towards a company in a unified manner, without being able to systematically account for differences in responses of individuals (Walsh and Beatty, 2007; Hong and Yang, 2009; Chun and Davies, 2010; Johnston and Everett, 2012; Helm and Tolsdorf, 2013). However, new studies are emerging that aim to explain varied responses within stakeholder groups (Mishina et al, 2012). These studies are based, for example, on identity and identification theories (Mael and Ashforth, 1992; Ahearne et al, 2005; Bhattacharya et al, 2009; Remke, 2013) or on the study of psychological concepts such as social axioms (i.e. deeply held beliefs about the world in general, such as cynicism and fate control) (West et al, 2015).

In summary, important research gaps in contemporary CR studies often relate to a need to better categorise CR outcomes, more fully understand the drivers of CR and to explore in depth the contingencies and moderators at play in how CR-related perceptions, emotions, beliefs and behaviour develop in individuals, above and beyond traditional stakeholder groupings. At the same time, there is a need to research CR within the contemporary business environment (see Ghobadian et al, 2016). Section 2 of this article will therefore explore these research gaps in light of macro business trends and Section 3 will propose a novel conceptual framework to outline interesting areas for future research. 


\section{Integration of contemporary CR research with macro business trends}

The research gaps identified in Section 1 mirror developments in wider business and society research and practice as scholars and practitioners alike suggest that the study of CR needs to change because the world and what we know about the world is changing (Money et al, 2016). In an attempt to integrate the academic need for CR advancement with developments of a rapidly changing business environment, this section explores macro business trends in light of CR theory and research. According to Ghobadian et al (2015), the following macro trends in the business environment will have a great impact on companystakeholder relationships in the coming decades:

- disparity of power between governments and business

- population growth, urbanisation and climate change

- electronic information and instantaneous connectivity between people.

The authors fully acknowledge that there are many other developmental issues that are important but not included in the above, but hope that by exploring the ones listed here this article provides a starting point for other scholars to add to.

\subsection{The need for better categorised outcomes of $C R$ - speaks to increasing disparities in business realities and the question of organisational purpose}

An increasing disparity between governments and large businesses, in which governments encounter constraints while businesses become increasingly powerful, suggests that organisations could more deeply consider their purpose and the outcomes they seek - and as such better categorise the consequences of $C R$. The authors invite researchers and practitioners to consider and develop key performance indicators as outcomes of CR that 
can more accurately reflect the stated purposes of organisations.

With many governments facing years of austerity following the recession in 2008 and the seemingly increasing divisions between nations, multinational corporations (through their wide reach and supply chains) are seen by many to be in a better position to address global issues, such as food and water security, social justice and equality, and the preservation of natural resources (Scherer and Palazzo, 2011; Austin and Seitanidi, 2012; Brammer et al, 2012). From a CR perspective, this poses interesting questions for organisations and their leadership: e.g. how far do organisations want to take on wider responsibilities, such as encouraging sustainable consumption or reducing obesity?

This emphasises the need for organisations to reflect and communicate issues relating to 'what are we trying to cause?' through their actions, and to choose key performance indicators (KPIs) that fit with their purpose (Holt and Littlewood, 2015). A global business such as Unilever, for example, is setting targets that relate not only to purchase figures, but to how people use Unilever products more sustainably. Without appropriate KPIs - which we label as consequences of reputation - organisations will not have the means to manage progress towards their goals. While the authors do not advocate a particular purpose for any organisation, it is interesting to reflect that recent research suggests, for example, that 'not acting', or 'not explaining inaction' on issues related to sustainability and fair work practices can have a negative impact on reputation (Korschun, 2015).

A systematic categorisation of meaningful outcomes of CR allows organisations and their leaders to carefully think through strategies and potential impacts with an end in mind, and will be integrated into the framework in Section 3 of this article in the following manner: following Money et al (2012b), outcomes of CR will be categorised in terms of a hierarchy 
that starts with affective outcomes (such as trust and positive emotions); moves to maintaining behaviours (such as staying in a relationship); and then moves to expanding behaviours that require discretionary effort (such as advocacy). This categorisation builds upon insights from psychology literature, which suggest that behaviour change is often slow and builds in increments from the current expression of behaviour (e.g. Unsworth et al, 2013; Davis et al, 2015). For example, if a person has low levels of affect and trust towards an organisation, it is often more difficult to influence positive advocacy than if someone started with a higher level of trust. A feature of current CR research is that it often seeks to understand desirable behaviours such as advocacy rather than exploring existing behaviours or attitudes in more depth and seeking incremental change. The authors propose a categorisation of behavioural outcomes as follows:

1. Maintain - continue with an existing behaviour - this could relate to behaviours that are directly beneficial to organisations, such as stakeholder retention and compliance, but could also include a broader set of behaviours, such as volunteering, or desirable end states, such as wellbeing, engagement or life satisfaction.

2. Stop - this involves stakeholders changing their behaviour and no longer engaging in certain activities. In many ways this is the most difficult outcome to influence because it involves changing of habits. This could involve behaviours directly linked to organisations, such as cessation of unsafe working practices, or those linked to broader societal outcomes, such as reducing overconsumption or substance misuse.

3. Start - this involves stakeholders either engaging in a new relationship (e.g. becoming an employee, customer etc.) or new action (e.g. starting to recycle, volunteer etc.), but may also involve stakeholders engaging more deeply with organisations (e.g. 
cooperating with organisations, providing more information, recommending initiatives on social media platforms) or changing the way that stakeholders engage in existing behaviours (e.g. this may include using products in more sustainable ways, such as washing clothes at a lower temperature, driving more economically, volunteering more often within a community).

The starting point of the above-suggested categorisation is the current behaviours of stakeholders - which are often seen as a useful lever to influence behaviour. For example, it may take different experiences to encourage someone to continue as opposed to start volunteering. Conceptually, ways of achieving such behavioural outcomes of maintain, stop and start are offered in exchange theory and reciprocity theory in stakeholder-organisation relationships. More specifically, this may include 'the firm offering something of value to stakeholders' before 'stakeholders offer something of value back to the organisation or society', in terms of specific maintain, stop or start behaviours (Money et al, 2012b: p. 8). Bhattacharya et al (2009) suggest that these 'offerings' might have a tangible or intangible nature.

Outcomes are deliberately placed at the end of the framework in Section 3. It is at this end that the authors would invite both scholars and practitioners to start their journey by asking questions such as 'What is the outcome we are seeking to understand or influence?' and 'What is the current state within the stakeholder universe?'. By doing so, the authors believe CR research can become truly strategic and be a force for organisations achieving outcomes including but beyond financial returns.

\subsection{The need for a wider range of causes of CR - speaks to changing norms, perceptions} and knowledge of issues such as climate change, urbanisation, population growth and 
increased electronic connectivity between individuals, as well as advances in the study of the psychology of perception

Issues such as climate change, urbanisation and population growth are no longer contested by mainstream academics, politicians and practitioners. This means that the causes of CR will increasingly depend on meeting expectations in relation to these issues, as CRs and organisational activities will be judged by stakeholders in light of these realities. At the same time, advances in the study of human perception provide a richer tapestry of theory through which causes of reputation can be understood.

The causes of $\mathrm{CR}$ are levers that reflect both underlying human psychology and changing societal expectations. Such changing expectations may, for example, result in a changing psychological contract between business and society in which organisations can reflect more openly on their purpose and consider how purpose can be co-created with stakeholders and can take account of the concerns of broader societal stakeholders (Ansari et al, 2012; Leach et al, 2012; Arend, 2013; Littlewood, 2014). The authors propose that within a perception-based approach to $C R$, the causes of $C R$ reside in stakeholder experiences. Critically, however, the authors propose that it will be useful to distinguish between the way experiences are categorised and also invite a wider set of causes to take advantage of both a better understanding of the psychology of experience as well as the changing nature of stakeholder expectations:

1. Functional drivers of $\mathbf{C R}$. These drivers are perhaps the most widely researched and used causes and have their origins in well-known measurement tools such as the Reputation Quotient (Fombrun et al, 2000), RepTrak ${ }^{\circledR}$ (Fombrun et al, 2015) and Most Admired Company Indicators. Categorisation of stakeholder experiences in terms of 
functions within an organisation relate, for example, to experiences of products and services, workplace environment, leadership and social responsibility.

2. Relational drivers of CR. These drivers are also well established in research and categorisation of stakeholder experiences is in terms of relational aspects such as experiences related to how well organisations inform, listen, keep commitments and provide benefits to stakeholders (e.g. Walsh et al, 2009b; Money et al, 2012b) - as well as more negative experiences that relate to the use or abuse of power by organisations (e.g. MacMillan et al, 2004; Money et al, 2012b).

3. Motivational drivers of CR. These drivers are emerging in the literature and build on advances in the study of psychology (e.g. Lawrence and Nohria, 2010). While some may see these as a subset of relational approaches, which can include both intrinsic and extrinsic benefits, the authors suggest that a specific exploration of motivational sources allows for a more precise lens to study how CR perceptions develop.

4. Third-party influence drivers of $\mathbf{C R}$. These drivers are experiences that reside in the communications that stakeholders receive from peers and other key influencers. This could include word or mouth, electronic word of mouth, blogging or more traditional advertising and public relations (see for example Edelman, 2016; Dyson and Money, 2017). While third-party influences are often outside of organisations' direct control, they are suggested to be a key reputation-building experience, and often include links between friends and family and observational learning (Bandura, 1986; Hillenbrand et al, 2011).

While functional and relational drivers are well discussed in CR literature, motivational drivers and third-party influence drivers are less so, and hence necessitate a brief example. 
As an example of motivational drivers of CR experiences, the approach utilised by Unilever is exemplified. Through its sustainable living plan, which aims to make sustainable living commonplace, Unilever has been able to engage with stakeholders to co-create solutions in relation to sustainability. More specifically, Unilever is exploring how engaging with its corporate and product brands can help its stakeholders to fulfil the following drives:

(1) drive to acquire - gain material goods and status commensurate with aspirations;

(2) drive to bond - be part of a group that cares for and gives identity; (3) drive for meaning - have a purpose that is bigger than yourself - combined with a drive to learn - understand the world around us; (4) drive to defend - protect the things that are important to us (building on Lawrence and Nohria, 2002; Lawrence, 2010; Ghobadian et al, 2015).

One key learning from the Unilever case has been that employees have been motivated to educate communities about sustainability, while wider society has been motivated by both defending what is important to them, but also gaining status in relation to sustainability. By looking at sustainability and sustainable behaviours as a function of fundamental human motivation, Unilever has differentiated itself from other organisations - and this is perhaps one of the reasons it has been so successful in this domain - with the sustainable living plan winning numerous awards - and sustainable living brands growing $50 \%$ faster than other Unilever brands that have yet to embrace this approach (Weed, 2017).

Finally, the impact of third-party influence drivers has had significant success, in particular in relation to public health campaigns - such as reduction in drink driving and the increase in seat-belt wearing (e.g. Vecino-Ortiz et al, 2014). In this context, years of messaging from governments regarding the risks and benefits of such behaviours, was found to have much less influence than messages given from the perspective of friends and family members - 
who provide a personal experience or opinion (Dyson and Money, 2017). The advent of social media and rating platforms extends the impact of peer-to-peer influence and the authors therefore advocate further study in this regard in relation to both commercial and non-commercial organisations.

\subsection{The need for deeper exploration of contingencies and moderators in CR research -} speaks to increased global connectivity and the possibility to broadcast and receive personalised views electronically; as well as to advances in the study of individual and cultural differences

Widespread access to electronic information combined with instantaneous connectivity between large numbers of individuals across geographic boundaries, who often strive to live more individualistically and broadcast personalised views easily and globally, exemplifies the importance of contingencies and moderators when studying reputation.

The communications industry, in all its facets, is at the forefront of unprecedented change right across the globe, which requires organisations to be more transparent in their relationships with stakeholders. The availability of personalised electronic communication and the availability of 'big data' offer opportunities for organisations to tailor communications towards individual stakeholders in a way that takes account of aspects that are specific to each individual (e.g. cultural background, demographics and personal beliefs), rather than in a blanket fashion or by stakeholder group. This poses both practical and ethical questions about the importance and use of contingency and moderators (FernandezFeijoo et al, 2014; Harjoto and Jo, 2014). 
When considering such contingencies, researchers may want to study moderation between causes and CR, between CR and outcomes, and direct links between causes and outcomes in terms of (but not limited to) the following factors:

1. Characteristics of the perceiver/stakeholder (i.e. the person experiencing, perceiving or behaving in a certain way) - this could link to that person's values, personality, social axioms, cognitive understanding, socioeconomic status, culture and sense-making etc. While demographic variables are useful, the authors suggest that these measures should be supplemented by specific cognitive and emotive influence factors that may better explain previously undiscovered underlying moderating mechanisms.

2. Characteristics of the messenger (i.e. the entity being experienced or perceived: usually an organisation or third-party influencer) - this could include aspects such as the credibility, intention, trustworthiness, knowledge and social identity of the messenger.

3. Characteristics of the context/relationship (i.e. the meta-characteristics of the context) - this could include the broader context in which the company-stakeholder relationship is framed, for example a long- or short-term relationship, a conflict-laden relationship or a partnership etc.

A case example of how contingencies can impact on the outcome of organisational action is illustrated by Elbel et al (2009): in the context of communicating about calories of meals in fast-food restaurants in New York it was assumed that simply communicating about calorie intake would reduce calorie consumption and associated health risks. While this was the case in some of the neighbourhoods, Elbel et al (2009) explain that calorie intake increased in the poorest neighbourhoods, which ironically were the ones primarily targeted with this health campaign. Subsequent research showed that in these environments people were 
conducting a cost/benefit analysis - i.e. how could they get the most calories for the least money - producing exactly the opposite outcome behaviour than the programme intended. If the design of the campaign and its associated research had included a moderator that took account of factors, such as socioeconomic status and people's beliefs systems, it may have been able to tailor messages to produce better outcomes.

From a managerial perspective, the importance of transparent, individualised and authentic communication can be understood in relation to factors such as the following (Pain, 2017): a need to be empathetic (organisations will need to demonstrate a real understanding and appreciation of the needs both of the planet and the people on it); a clarity of purpose and message (organisations need to know who they are and what they stand for if they are to be seen and heard in today's media space); and engagement in alliances and collaboration (issues are now bigger than any one individual, government, corporation or country - the world is a highly interconnected place and will require far more collective responsibility than has been the case so far).

\section{Reputation framework and outlook on CR research}

Before integrating the insights from Section 2 of this article into the novel reputation framework presented below, with the purpose of guiding future studies in this field, a final aspect in CR research needs exploration: CR, at its heart, is typically defined as the perception of a character (Fombrun, 1996). It is therefore important that the study of CR integrates advances in knowledge about the nature and development of perceptions and attitudes. Key aspects in this regard relate to advances in the understanding of how cognitive and emotional aspects develop, interact and how they impact on perceptions, in 
particular perceptions about a character, or characteristic of an entity (Dolcos and Denkova, 2014).

Much reputation research is based on the theory of reasoned action (Fishbein and Ajzen, 1975; Ajzen and Fishbein, 2000; Ajzen, 2012), which proposes that emotional reactions result from a cognitive assessment. Other theories, however, suggest that emotional reactions may precede cognitive assessment or occur in parallel and at the very least that cognitive and emotional perceptions influence each other (Pessoa, 2013; Braver et al, 2014). The authors therefore propose that CR research takes account of this development and more explicitly differentiates between cognitive and emotional elements in a way that recognises both and aims to categorise CR equally in terms of cognitive and emotional elements as follows:

1. Cognitive aspects - such as beliefs or judgements - can be used for differentiation, as beliefs or judgements are not by their nature 'positive' or 'negative'. For example a reputation for being highly technical, modern or even competent could be positive or negative depending on the perspective of the person making a judgement.

2. Emotional aspects - such as feelings or attitudes - can be used for benchmarking and may be seen as outputs in certain circumstances. Factors that are important in this regard include stakeholder trust in organisations, as well as the level of respect and admiration that stakeholders have for an organisation.

Integrating cognitive and emotional aspects alongside earlier (in Section 2) discussed categorisations of CR outcomes, drivers and moderators, results in the novel reputation framework displayed in Figure 2. A key factor differentiating reputation from outcomes of reputation in that framework is that the focus of perceptions and feelings with regards to 
reputation is always the organisation, i.e. how much the organisation is trusted, admired or respected, or the extent to which it is believed to have certain characteristics, i.e. how modern, traditional or innovative it is. Outcomes of CR, on the other hand, relate to stakeholder behaviours, which can be directed towards the organisation or can be directed elsewhere: one of the key messages of this article is that in considering organisational purpose more broadly consequences may also include behaviours, intentions and end states, such as prosocial behaviours and the wellbeing of stakeholders, that go beyond more instrumental and organisation-focused behaviours.

[Figure 2 about here]

As can be seen in Figure 2, the framework can be explored from an organisation-oriented perspective (in terms of strategic actions, intangible assets and KPIs) as well as from a stakeholder-oriented perspective (in terms of experiences/observations, feelings/beliefs and intentions/behaviours). It is important to note that the authors expect the organisation and stakeholder perspectives to reflect one another as they are two sides of the same coin, concepts that can be seen as equivalent. If relationships flourish - this allows strategic aims to be fulfilled. Causes of CR from an organisation-oriented perspective would translate into strategic actions, while causes of CR from a stakeholder-oriented perspective represent experiences or observations related in some way to these strategic actions. When considering CR, an organisation may consider it as 'goodwill' or as an 'intangible asset' which from a stakeholder-oriented perspective corresponds to the trust, admiration and esteem in which stakeholders holds an organisation. Finally, in terms of strategic outcomes, an organisation may consider KPIs such as the extent of sustainable consumption, employee 
engagement or community wellbeing (Money et al, 2009), while for stakeholders this would translate into behaviours or end-states for each individual stakeholder.

It should also be noted that there is a feedback loop linking outcomes of CR back to causes of CR. In this way scholars and practitioners are invited to learn from research and current behaviours and use these as inputs to guide future actions. A feedback loop also allows for the calculation of return on investment for certain strategic actions: the cost of a strategic action can be calculated in terms of the benefit of the behaviour it creates. For prosocial behaviours, such as sustainable consumption, it may be possible to link campaigns to litres of water saved, or the amount of waste not going to landfill (Holt and Littlewood, 2015). For government-related campaigns it may be possible to link strategic actions to extended life expectancy, increased health within society and possibly even lives saved - while at the same time exploring the cost and impact of the strategic actions involved. The framework also supports researchers aiming to utilize controlled experiments that could create different experiences for stakeholders and, as such, measure the impact of these actions on outcomes.

\subsection{Direct links between causes and consequences of CR: the role of corporate communications}

A number of researchers in CR, as well as wider management areas, suggest to directly link what are labelled causes and consequences in the above framework without $C R$ as a mediating variable (Money et al, 2009). The benefit of such approaches is to provide insights that directly link strategic action to observable outcome, and this may be useful to study specific organisational action in the most parsimonious way possible, without including all explanatory variables. In particular, the exploration of direct impacts may be of use to those 
exploring the impact of corporate communications in relation to encouraging behavioural outcomes in stakeholders (Saraeva, 2017). While corporate communications can be seen as a subset of the relational experiences that may drive CR and its associated consequences in stakeholder perception, it is worth noting that corporate communications (rather than other aspects of stakeholder experiences) are under the control of organisations and may therefore form the foundation of campaigns aimed at bringing about positive behaviour change for social or other good. As such, the framework could be used to explore the impact of messages sent by the organisation and other stakeholders and the impact that these messages have on outcomes directly.

In these circumstances the organisation would be seen to be operating as a messenger and as such the impact of its message on stakeholder behaviour may or may not be mediated or moderated by $\mathrm{CR}$ and other factors. For example, an organisation sending a message to stakeholders in regards to consuming products more sustainably would presumably have a bigger positive impact on stakeholder behaviour if it had a positive and trusted reputation in relation to sustainability issues (than if it were seen to have a reputation for greenwash). The exploration of message-messenger interaction is explored in depth by Saraeva (2017) and the authors warmly welcome studies that seek to more deeply unpack the role of corporate communications and third-party influence and explore the reputation of messengers (be they corporate or third party) as mediators or possibly moderators.

\subsection{A note for the future}

In terms of a future outlook on proposed CR research, the authors believe that the concepts and categorisations provided in Figure 2 will allow us to achieve a number of future 
ambitions and allow researchers to follow new paths in CR studies, three of which are briefly summarised below.

First, in exploring the outcomes and consequences of $\mathrm{CR}$, the framework integrates different perspectives to explore aspects of organisational purpose. As such, the framework can be utilised to research and manage issues that may by some be perceived as paradoxes: such as short vs long-term interests; internal vs external change processes, companyoriented vs stakeholder-oriented approaches and organisation vs societal benefits. For such studies, the authors suggest to determine specific KPIs that can be measured simply, in terms of stakeholder behaviour, intention or end-states, and can be traced back to strategic action and stakeholder experiences and observations thereof.

Second, in exploring causes or drivers of CR, the framework leverages advances in psychology, which will be of particular use and interest to the relational/perception-based approach to CR: while human nature may be causing many of the problems that the world is currently facing, levering a deeper understanding of human nature can provide solutions in that regard (as exemplified earlier in the Unilever Sustainable Living example). As such the framework proposes ways to humanise and influence exchanges between stakeholders as a way to build bridges between people as well as between people and business (Money et al, 2016). The framework also proposes ways to balance ambitions of business and society and for both to be embedded and measured in stakeholder experience: i.e. rather than just stopping certain behaviours the framework can be used to support starting alternative behaviours and, as such, can allow business to become more of a force for good.

Third, in terms of research context and research process, the framework allows us to integrate contextual developments, such as a rise in identity politics and the rise and fall of 
diversity of opinion (i.e. while people tend to talk to more people facilitated through electronic tools, the diversity of opinion often appears smaller). It acknowledges the growing power of stakeholders through social media; and implies a need for more transparency, more honest communication and more connections between corporations and the recipients of CRs (Walsh et al, 2016). Importantly, the framework conceptualises reputation management as a process that has a feedback loop, which allows businesses to be both values and stakeholder led in their purpose; and to rethink the purpose of business from a societal perspective (Waddock, 2000), i.e. in terms of setting, co-creating and meeting expectations; and in terms of understanding stakeholders as individuals, citizens or people with a wider purpose than functional roles such as consumers, employees or citizens. 


\section{Bibliography}

Ahearne, M., Bhattacharya, C. B. and Gruen, T. (2005) Antecedents and consequences of customer-company identification: expanding the role of relationship marketing. Journal of Applied Psychology 90(3), 574-585.

Ajzen, I. and Fishbein, M. (2000) Attitudes and the attitude-behavior relation: reasoned and automatic processes. European Review of Social Psychology 11(1), 1-33.

Albert, S. and Whetten, D. A. (1985) Organizational identity. In: L. L. Cummings and B. M. Staw (eds.) Research in Organizational Behaviour. Greenwich, CT: JAI Press, pp. 263295.

Amit, R. and Schoemaker, P. J. (1993) Strategic assets and organizational rent. Strategic Management Journal 14(1), 33-46.

Anderson, E. and Weitz, B. (1992) The use of pledges to build and sustain commitment in distribution channels. Journal of Marketing Research 29(1), 18-34.

Ansari, S., Munir, K. and Gregg, T. (2012) Impact at the 'bottom of the pyramid': the role of social capital in capability development and community empowerment. Journal of Management Studies 49(4), 813-842.

Arend, R. J. (2013) A heart-mind-opportunity nexus: distinguishing social entrepreneurship for entrepreneurs. Academy of Management Review 38(2), 313-315.

Argenti, P. A. and Druckenmiller, B. (2004) Reputation and the corporate brand. Corporate Reputation Review 6(4), 368-374.

Arnold, J., Coombs, C., Wilkinson, A., Loan-Clarke, J., Park, J. and Preston, D. (2003) Corporate images of the United Kingdom National Health Service: implications for 
the recruitment and retention of nursing and allied health profession staff. Corporate Reputation Review 6(3), 223-238.

Ashforth, B., Harrison, S. and Corley, K. (2008) Identification in organizations: an examination of four fundamental questions. Journal of Management 34(3), 325-374.

Ashforth, B. E., Joshi, M., Anand, V. and O'Leary-Kelly, A. M. (2013) Extending the expanded model of organizational identification to occupations. Journal of Applied Social Psychology 43(12), 2426-2448.

Austin, J. E. and Seitanidi, M. M. (2012) Collaborative value creation: a review of partnering between nonprofits and businesses. Part 2: Partnership processes and outcomes. Nonprofit and Voluntary Sector Quarterly 41(6), 929-968.

Bagwell, K. (1992) Pricing to signal product line quality. Journal of Economics and Management Strategy 1(1), 151-174.

Balmer, J. M. T. (1998) Corporate identity and the advent of corporate marketing. Journal of Marketing Management 14(8), 963-996.

Balmer, J. M. T. and Greyser, S. A. (2003) Revealing the Corporation. Perspectives on Identity, Image, Reputation, Corporate Branding and Corporate-Level Marketing. London: Routledge.

Bandura, A. (1986) Social Foundations of Thought and Action: a Social Cognitive Theory. Englewood Cliffs, NJ: Prentice Hall.

Bantimaroudis, P. and Zyglidopoulos, S. C. (2014) Cultural agenda setting: salient attributes in the cultural domain. Corporate Reputation Review 17(3), 183-194. 
Barlow, W. G. and Payne, S. L. (1949) A tool for evaluating company community relations. Public Opinion Quarterly 13(3), 405-414.

Barnett, M. L. (2006) Waves of collectivizing: a dynamic model of competition and cooperation over the life of an industry. Corporate Reputation Review 8(4), 272-292.

Barnett, M. L., Jermier, J. M. and Lafferty, B. A. (2006) corporate reputation: the definitional landscape. Corporate Reputation Review 9(1), 26-38.

Barney, J. (1991) Firm resources and sustained competitive advantage. Journal of Management 17(1), 99-120.

Bartikowski, B., Walsh, G. and Beatty, S. E. (2011) Culture and age as moderators in the corporate reputation and loyalty relationship. Journal of Business Research 64(9), 966-972.

Basdeo, D. K., Smith, K. G., Grimm, C. M., Rindova, V. P. and Derfus, P. J. (2006) The impact of market actions on firm reputation. Strategic Management Journal 27(12), 12051219.

Beatty, S. E., Givan, A. M., Franke, G. R. and Reynolds, K. E. (2015) Social store identity and adolescent females' store attitudes and behaviors. Journal of Marketing Theory and Practice 23(1), 38-56.

Bennett, R. and Kottasz, R. (2000) Practitioner perceptions of corporate reputation: an empirical investigation. Corporate Communications: An International Journal 5(4), 224-235. 
Berens, G. and van Riel, C. B. M. (2004) Corporate associations in the academic literature: three main streams of thought in the reputation measurement literature. Corporate Reputation Review 7(2), 161-178.

Bergh, D. D., Ketchen, D. J., Boyd, B. K. and Bergh, J. (2010) New frontiers of the reputationperformance relationship: insights from multiple theories. Journal of Management $36(3), 620-632$.

Besiou, M., Hunter, M. L. and Van Wassenhove, L. N. (2013) A web of watchdogs: stakeholder media networks and agenda-setting in response to corporate initiatives. Journal of Business Ethics 118(4), 709-729.

Bhattacharya, C., Korschun, D. and Sen, S. (2009) Strengthening stakeholder-company relationship through mutually beneficial corporate social responsibility initiatives. Journal of Business Ethics 85, 257-272.

Bhattacharya, C. B. and Sen, S. (2003) Consumer-company identification: a framework for understanding consumers' relationships with companies. Journal of Marketing 67(2), 76-88.

Bolger Jr, J. F. (1959) How to evaluate your company image. Journal of Marketing 24(2), 710.

Boyd, B. K., Bergh, D. D. and Ketchen Jr, D. J. (2010) Reconsidering the reputationperformance relationship: a resource-based view. Journal of Management 36(3), $588-609$. 
Brammer, S., Jackson, G. and Matten, D. (2012) Corporate social responsibility and institutional theory: new perspectives on private governance. Socio-Economic Review 10(1), 3-28.

Braver, T. S., Krug, M. K., Chiew, K. S. et al (2014) Mechanisms of motivation-cognition interaction: challenges and opportunities. Cognitive, Affective and Behavioral Neuroscience 14(2), 443-472.

Bromley, D. B. (1993) Reputation. Image and Impression Management. London: Wiley.

Bromley, D. B. (2001) Relationships between personal and corporate reputation. European Journal of Marketing 35(3/4), 316-334.

Brown, B. and Logsdon, J. M. (1999) Corporate reputation and organization identity as constructs for business and society research. Proceedings of the Tenth Annual Meeting of the International Association for Business and Society (Paris, France).

Broom, G., Casey, S. and Ritchey, J. (2000) Toward a concept and theory of organizationpublic relationships: an update. In: J. A. Ledingham and S. D. Bruning (eds.) Public Relations as Relationship Management: A Relational Approach to Public Relations. Mahwah, NJ: Lawrence Erlbaum Associates, Inc., pp. 3-22.

Brown, T. J. (1998) Corporate associations in marketing: antecedents and consequences. Corporate Reputation Review 1(3), 215-233.

Brown, T. J., Dacin, P. A., Pratt, M. G. and Whetten, D. A. (2006) Identity, intended image, construed image, and reputation: an interdisciplinary framework and suggested terminology. Journal of the Academy of Marketing Science 34(2), 99-106. 
Cable, D. M. and Graham, M. E. (2000) The determinants of job seekers' reputation perceptions. Journal of Organizational Behavior 21(80), 929-947.

Cai, H., Jin, G. Z., Liu, C. and Zhou, L.-a. (2014) Seller reputation: from word-of-mouth to centralized feedback. International Journal of Industrial Organization 34, 51-65.

Carmeli, A. and Tishler, A. (2004a) The relationships between intangible organizational elements and organizational performance. Strategic Management Journal 25(13), 1257-1278.

Carmeli, A. and Tishler, A. (2004b) Resources, capabilities, and the performance of industrial firms: a multivariate analysis. Managerial and Decision Economics 25(6/7), 299-315.

Carroll, C. (2009) Defying a reputational crisis - Cadbury's salmonella scare: why are customers willing to forgive and forget? Corporate Reputation Review 12(1), 64-82.

Carroll, C. (2010) Corporate Reputation and the News Media: Agenda-Setting within Business News Coverage in Developed, Emerging, and Frontier Markets. London: Routledge/Taylor \& Francis.

Carroll, C. E. (2013) Corporate communication and the multi-disciplinary field of communication. In: Carroll, G. (ed.) The Handbook of Communication and Corporate Reputation. Chichester, UK: Wiley-Blackwell.

Carroll, C. E. and McCombs, M. (2003) Agenda-setting effects of business news on the public's images and opinions about major corporations. Corporate Reputation Review 6(1), 36-46. 
Carter, S. M. and Ruefli, T. W. (2006) Intra-industry reputation dynamics under a resourcebased framework: assessing the durability factor. Corporate Reputation Review 9(1), $3-25$.

Caruana, A. and Ewing, M. T. (2010) How corporate reputation, quality, and value influence online loyalty. Journal of Business Research 63(9), 1103-1110.

Caruana, A., Cohen, C. and Krentler, K. A. (2006) Corporate reputation and shareholders' intentions: an attitudinal perspective. Journal of Brand Management 13(6), 429-440.

Caves, R. E. and Porter, M. E. (1977) From entry barriers to mobility barriers: conjectural decisions and contrived deterrence to new competition. Quarterly Journal of Economics 91(2), 241-261.

Chang, H. H., Tsai, Y.-C., Wong, K. H., Wang, J. W. and Cho, F. J. (2015) The effects of response strategies and severity of failure on consumer attribution with regard to negative word-of-mouth. Decision Support Systems 71, 48-61.

Christian, R. C. (1959) Industrial marketing... how important is the corporate image? Journal of Marketing 24(2), 79-80.

Chun, R. (2001) European Journal of Marketing, special edition: 'Corporate identity and corporate marketing'. Corporate Reputation Review 4(3), 276-283.

Chun, R. (2005) Corporate reputation: meaning and measurement. International Journal of Management Reviews 7(2), 91-109.

Chun, R. and Davies, G. (2010) The effect of merger on employee views of corporate reputation: time and space dependent theory. Industrial Marketing Management 39(5), 721-727. 
Cloninger, D. O. (1995) Managerial goals and ethical behavior. Financial Practice and Education 5(1), 50-59.

Cornelissen, J. P., Haslam, S. A. and Balmer, J. M. T. (2007) social identity, organizational identity and corporate identity: towards an integrated understanding of processes, patternings and products. British Journal of Management 18(1), 1-16.

Courtright, J. L. and P. M. Smudde (2009) Leveraging organizational innovation for strategic reputation management. Corporate Reputation Review 12(3), 245-269.

Davies, G. and Miles, L. (1998) Reputation management: theory versus practice. Corporate Reputation Review 2(1), 16-27.

Davies, G. and Olmedo-Cifuentes, I. (2016) Corporate misconduct and the loss of trust. European Journal of Marketing 50(7/8), 1426-1447.

Davies, G., Chun, R., da Silva, R. V. and Roper, S. (2001) The personification metaphor as a measurement approach for corporate reputation. Corporate Reputation Review 4(2), $113-127$.

Davies, G., Chun, R., daSilva, R. and Roper, S. (2003) Corporate Reputation and Competitiveness. London: Routledge.

Davis, R., Campbell, R., Hildon, Z., Hobbs, L. and Michie, S. (2015) Theories of behaviour and behaviour change across the social and behavioural sciences: a scoping review. Health Psychology Review 9(3), 323-344.

de Chernatony, L. and Riley, F. D. O. (1998) Defining a 'brand': beyond the literature with experts' interpretations. Journal of Marketing Management 14(5), 417-443. 
Deephouse, D. (2000) Media reputation as a strategic resource: an integration of mass communication and resource-based theories. Journal of Management 26(6), 10911112.

Deephouse, D. L. and Carter, S. M. (2005) An examination of differences between organizational legitimacy and organizational reputation. Journal of Management Studies 42(2), 329-360.

Deephouse, D. L., Newburry, W. and Soleimani, A. (2016) The effects of institutional development and national culture on cross-national differences in corporate reputation. Journal of World Business 51(3), 463-473.

DiMaggio, P. J. and Powell, W. W. (2000) The iron cage revisited institutional isomorphism and collective rationality in organizational fields. Economics Meets Sociology in Strategic Management 17, 143-166.

Dolcos, F. and Denkova, E. (2014) Current emotion research in cognitive neuroscience: linking enhancing and impairing effects of emotion on cognition. Emotion Review 6(4), 362-375.

Dollinger, M. M. J., Golden, P. A. and Saxton, T. (1997) The effect of reputation on the decision to joint venture. Strategic Management Journal 18(2), 127-140.

Dowling, G. R. (1986) Managing your corporate images. Industrial Marketing Management 15(2), 109-115.

Dowling, G. R. (1993) Developing your company image into a corporate asset. Long Range Planning 26(2), 101-109. 
Dowling, G. R. (2004) Corporate reputations: should you compete on yours? California Management Review 46(3), 19-36.

Dowling, G. R. (2016) Defining and measuring corporate reputations. European Management Review 13(3), 207-223.

Dowling, G. and Moran, P. (2012) Corporate reputations: built in or bolted on? California Management Review 54(2), 25-42.

Dunne, E. (1974) How to discover your company's reputation. Management Review, 52-54.

Dutton, J. and Dukerich, J. (1991) Keeping an eye on the mirror: image and identity in organizational adaptation. Academy of Management Journal 34(3), 517-554.

Dutton, J. E., Dukerich, J. M. and Harquail, C. V. (1994) Organizational images and member identification. Administrative Science Quarterly 39, 239-263.

Dyson, T. and Money, K. (2017) Introducing the Channel Strategy Model: how to optimise value from third party influence. Henley Discussion Paper series JMC-2017-01. Henley Business School, University of Reading.

Eberle, D., Berens, G. and Li, T. (2013) The impact of interactive corporate social responsibility communication on corporate reputation. Journal of Business Ethics 118(4), 731-746.

Edelman (2016) Trust Barometer. www.edelman.com/insights/intellectual-property/2016edelman-trust-barometer, accessed on 31 July 2017.

Einwiller, S. A., Carroll, C. E. and Korn, K. (2010) Under what conditions do the news media influence corporate reputation? The roles of media dependency and need for orientation. Corporate Reputation Review 12(4), 299-315. 
Elbel, B., Kersh, R., Brescoll, V. L., Dixon, L. B. (2009) Calorie labelling and good choices: a first look at the effects on low-income people in New York City. Health Affairs 28(6), $1110-1121$.

Elsbach, K. D. (1994) Managing organizational legitimacy in the california cattle industry: the construction and effectiveness of verbal accounts. Administrative Science Quarterly $39,57-88$.

Ettorre, B. (1996) The care and feeding of a corporate reputation. Management Review 85(6), 39-42.

Fernandez-Feijoo, B., Romero, S. and Ruiz, S. (2014) Effect of stakeholders' pressure on transparency of sustainability reports within the GRI framework. Journal of Business Ethics 122(1), 53-63.

Fillis, I. (2003) Image, reputation and identity issues in the arts and crafts organization. Corporate Reputation Review 6(3), 239-251.

Fishbein, M. and Ajzen, I. (1975) Belief, Attitude, Intention and Behavior: An Introduction to Theory and Research. Reading, MA: Addison-Wesley.

Fombrun, C. J. (1996) Reputation: Realizing Value From the Corporate Image. Boston: Harvard Business School Press.

Fombrun, C. (2012) The building blocks of corporate reputation; definitions, antecedents, consequences. In: Barnett, M. and Pollock, T. (eds.) The Oxford Handbook of Corporate Reputation. Oxford: Oxford University Press.

Fombrun, C. and Shanley, M. (1990) What's in a name? Reputation building and corporate strategy. Academy of Management Journal 33(2), 233-258. 
Fombrun, C. and van Riel, C. (1997) The reputational landscape. Corporate Reputation Review 1(1/2), 5-13.

Fombrun, C., Gardberg, N. and Sever, J. (2000) The reputation quotient: a multi-stakeholder measure of corporate reputation. Journal of Brand Management 7(4), 241-255.

Fombrun, C. J., Ponzi, L. J. and Newburry, W. (2015) stakeholder tracking and analysis: the Reptrak $^{\circledast}$ system for measuring corporate reputation. Corporate Reputation Review 18(1), 3-24.

Foremann, P., Whetten, D. and Mackey, A. (2013) An identity-based view of reputation, image, and legitimacy: clarifications and distinctions among related constructs. In: Barnett, M. and Pollock, T. (eds.) The Oxford Handbook of Corporate Reputation. Oxford: Oxford University Press.

Freeman, R. E. (1984) Strategic Management: A Stakeholder Approach. Boston: Pitman.

Freeman, R. E. (2010) Strategic Management: A Stakeholder Approach. Cambridge: Cambridge University Press.

Fryxell, G. E., Wang, J. and Jia, W. (1994) The Fortune corporate 'reputation' index: reputation for what? Journal of Management 20(1), 1-14

Gabbioneta, C., Ravasi, D. and Mazzola, P. (2007) Exploring the drivers of corporate reputation: a study of Italian securities analysts. Corporate Reputation Review 10(2), 99-123.

Gardberg, N. A. and Fombrun, C. J. (2002) The global reputation quotient project: first steps towards a cross-nationally valid measure of corporate reputation. Corporate Reputation Review 4(4), 303. 
Gardberg, N. A., Symeou, P. C. and Zyglidopoulos, S. C. (2015) Public trust's duality in the CSP-reputation-financial performance relationship across countries. Academy of Management Proceedings (Meeting Abstract Supplement) (2015(1), 15705.

Garnelo-Gomez, I., Littlewood, D. and Money, K. (2015) Understanding the identity and motivations of sustainable consumers: a conceptual framework. Paper presented at the British Academy of Management Conference, Portsmouth, UK, September 2015.

Gassenheimer, J. B., Houston, F. S. and Davis, J. C. (1998) The role of economic value, social value, and perceptions of fairness in interorganizational relationship retention decisions. Journal of the Academy of Marketing Science 26(4), 322-337.

Ghobadian, A., Money, K. and Hillenbrand, C. (2015) Corporate responsibility research: past-present-future. Group \& Organization Management 40(3), 271-294.

Gioia, D. A. and Thomas, J. B. (1996) Identity, image, and issue interpretation: sensemaking during strategic change in academia. Administrative Science Quarterly 41(3), 370403.

Goldberg, M. E. and Hartwick, J. (1990) The effects of advertiser reputation and extremity of advertising claim on advertising effectiveness. Journal of Consumer Research 17(2), 172-179.

Greenwood, M. (2007) Stakeholder engagement: beyond the myth of corporate responsibility. Journal of Business Ethics 74(4), 315-327.

Grunig, J. E. (1993) Image and substance: from symbolic to behavioral relationships. Public Relations Review 19(2), 121-139. 
Hall, R. (1992) The strategic analysis of intangible resources. Strategic Management Journal 13(2), 135-144.

Hall, R. (1993) A framework linking intangible resources and capabiliites to sustainable competitive advantage. Strategic Management Journal 14(8), 607-618.

Hammond, S. A. and Slocum Jr., J. W. (1996) The impact of prior firm financial performance on subsequent corporate reputation. Journal of Business Ethics 15(2), 159-165.

Hansen, H., Samuelsen, B. M. and Silseth, P. R. (2008) Customer perceived value in B-T-B service relationships: investigating the importance of corporate reputation. Industrial Marketing Management 37(2), 206-217.

Hanson, D. and Stuart, H. (2001) Failing the reputation management test: the case of BHP, the big Australian. Corporate Reputation Review 4(2), 128-143.

Harjoto, M. A. and Jo, H. (2015) Legal vs. normative CSR: differential impact on analyst dispersion, stock return volatility, cost of capital, and firm value. Journal of Business Ethics 128(1), 1-20.

Helm, S. (2007) The role of corporate reputation in determining investor satisfaction and loyalty. Corporate Reputation Review 10(1), 22-37.

Helm, S. (2011a) Corporate reputation: an introduction to a complex construct. In: S. Helm, K. Liehr-Gobbers and C. Storck (eds.) Reputation Management. Berlin, Heidelberg: Springer.

Helm, S. (2011b) Employees' awareness of their impact on corporate reputation. Journal of Business Research 64(7), 657-663. 
Helm, S. (2013) A matter of reputation and pride: associations between perceived external reputation, pride in membership, job satisfaction and turnover intentions. British Journal of Management 24(4), 542-556.

Helm, S. and Tolsdorf, J. (2013) How does corporate reputation affect customer loyalty in a corporate crisis? Journal of Contingencies and Crisis Management 21(3), 144-152.

Herbig, P. and Milewicz, J. (1993) The relationship of reputation and credibility to brand success. Journal of Consumer Marketing 10(3), 18-24.

Heslop, L. A., Nadeau, J., O’Reilly, N. and Armenakyan, A. (2013) Mega-event and country co-branding: image shifts, transfers and reputational impacts. Corporate Reputation Review 16(1), 7-33.

Hillenbrand, C., Money, K. and Ghobadian, A. (2011) Unpacking the mechanism by which corporate responsibility impacts stakeholder relationships. British Journal of Management 24(1), 127-146.

Holt, D. and Littlewood, D. (2015) Identifying, mapping, and monitoring the impact of hybrid firms. California Management Review 57(3), 107-125.

Hong, S. Y. and Yang, S.-U. (2009) Effects of reputation, relational satisfaction, and customer-company identification on positive word-of-mouth intentions. Journal of Public Relations Research 21(4), 381-403.

Hosmer, L. T. and Kiewitz, C. (2005) Organizational justice: a behavioral science concept with critical implications for business ethics and stakeholder theory. Business Ethics Quarterly 15(1), 67-91. 
Huang, Y. H. (1998) Public relations strategies and organization? Public relationships. In: Association for Education in Journalism and Mass Communication, Baltimore, MD, USA, August 5-8, 1998.

Johnston, K. A. and Everett, J. L. (2012) employee perceptions of reputation: an ethnographic study. Public Relations Review 38(4), 541-554.

Johnston, T. (2002) Superior seller reputation yields higher prices: evidence from online auctions. Marketing Management Journal 13(1), 108-117.

Keh, H. T. and Xie, Y. (2009) Corporate reputation and customer behavioral intentions: the roles of trust, identification and commitment. Industrial Marketing Management 38(7), 732-742.

Kiousis, S., Popescu, C. and Mitrook, M. (2007) Understanding influence on corporate reputation: an examination of public relations efforts, media coverage, public opinion, and financial performance from an agenda-building and agenda-setting perspective. Journal of Public Relations Research 19(2), 147-165.

Kitchen, P. J. and Laurence, A. (2003) Corporate reputation: an eight-country analysis. Corporate Reputation Review 6(2), 103-117.

Korschun, D. (2015) Boundary-spanning employees and relationships with external stakeholders: a social identity approach. Academy of Management Review 40(4), 611-629.

Korschun, D. and Du, S. (2013) How virtual corporate social responsibility dialogs generate value: a framework and propositions. Journal of Business Research 66(9), 14941504. 
Korschun, D., Bhattacharya, C. B. and Swain, S. D. (2014) Corporate social responsibility, customer orientation, and the job performance of frontline employees. Journal of Marketing 78(3), 20-37.

Kreiner, G. E. and Ashforth, B. E. (2004) Evidence toward an expanded model of organizational identification. Journal of Organizational Behavior 25(1), 1-27.

Kreps, D. M. and Wilson, R. (1982) Reputation and imperfect information. Journal of Economic Theory 27(2), 253-279.

Lange, D., Lee, P. M. and Dai, Y. (2011) Organizational reputation: a review. Journal of Management 37(1), 153-184.

Lambe, C. J., Wittmann, C. M. and Spekman, R. E. (2001) Social exchange theory and research on business-to-business relational exchange. Journal of Business-toBusiness Marketing 8(3), 1-36.

Lawrence, P. R. (2010) Driven to Lead: Good, Bad and Misguided Leadership. San Francisco, CA: Jossey-Bass.

Lawrence, P. R. and Nohria, N. (2002) Driven: How Human Nature Shapes our Choices. San Francisco, CA: Jossey-Bass.

Leach, M., Rockström, J., Raskin, P. et al (2012) Transforming innovation for sustainability. Ecology and Society 17(2), 11-16.

Lee, Y., Wanta, W. and Lee, H. (2015) Resource-based public relations efforts for university reputation from an agenda-building and agenda-setting perspective. Corporate Reputation Review 18(3), 195-209. 
Lewellyn, P. G. (2002) Corporate reputation: focusing the zeitgeist. Business and Society 41(4), 446-455.

Li, T., Berens, G. and de Maertelaere, M. (2013) Corporate Twitter channels: the impact of engagement and informedness on corporate reputation. International Journal of Electronic Commerce 18(2), 97-126.

Liedong, T. A., Ghobadian, A., Rajwani, T. and O'Regan, N. (2015) Toward a view of complementarity: trust and policy influence effects of corporate social responsibility and corporate political activity. Group and Organization Management 40(3), 405427.

Littlewood, D. (2014) 'Cursed'communities? Corporate social responsibility (CSR), company towns and the mining industry in Namibia. Journal of Business Ethics 120(1), 39-63.

Lloyd, S. (2011) Triangulation research to inform corporate reputation theory and practice. Corporate Reputation Review 14(3), 221-233.

Love, E. G. and Kraatz, M. (2009) Character, conformity, or the bottom line? How and why downsizing affected corporate reputation. Academy of Management Journal 52(2), 314-335.

Love, E. G. and Kraatz, M. S. (2017) Failed stakeholder exchanges and corporate reputation: the case of earnings misses. Academy of Management Journal 60(3), 880-903.

Maathuis, O., Rodenburg, J. and Sikkel, D. (2004) Credibility, emotion or reason? Corporate Reputation Review 63(4), 333-345.

MacLeod, J. S. (1967) The effect of corporate reputation on corporate success. Management Review 56(10), 67-71. 
MacMillan, K., Money, K. and Downing, S. J. (2000) Successful business relationships. Journal of General Management 26(1), 69-83.

MacMillan, K., Money, K., Downing, S. et al (2004) Giving your organisation SPIRIT: an overview and call to action for directors on issues of corporate governance, corporate reputation and corporate responsibility. Journal of General Management 30(2), 15-41.

MacMillan, K., Money, K., Downing, S. and Hillenbrand, C. (2005) Reputation in relationships: measuring experiences, emotions and behaviors. Corporate Reputation Review 8(3), 214-232.

Mael, F. and Ashforth, B. E. (1992) Alumni and their alma mater: a partial test of the reformulated model of organizational identification. Journal of Organizational Behavior 13(2), 103-123.

Mahon, J. F. and Wartick, S. L. (2003) Dealing with stakeholders: how reputation, credibility and framing influence the game. Corporate Reputation Review 6(1), 19-35.

Mahon, J. F., Heugens, P. P. and Lamertz, K. (2004) social networks and non-market strategy. Journal of Public Affairs 4(2), 170-189.

McGuire, J. B., Scheeweis, T. and Branch, B. (1990) Perceptions of firm quality: a cause or result of firm performance. Journal of Management 16(1), 167-180.

Miles, M. P. and Covin, J. G. (2000) Environmental marketing: a source of reputational, competitive, and financial advantage. Journal of Business Ethics 23(3), 299-311.

Milgrom, P. and Roberts, J. (1982) Predation, reputation, and entry deterrence. Journal of Economic Theory 27(2), 280-312. 
Milgrom, P. and Roberts, J. (1986) Relying on the information of interested parties. RAND Journal of Economics 17(1), 18-32.

Mishina, Y., Block, E. S. and Mannor, M. J. (2012) The path dependence of organizational reputation: how social judgment influences assessments of capability and character. Strategic Management Journal 33(5), 459-477.

Mitchell, R. K., Agle, B. R. and Wood, D. J. (1997) Toward a theory of stakeholder identification and salience: defining the principle of who and what really counts. Academy of Management Review 22(4), 853-886.

Money, K. and Hillenbrand, C. (2006) Using reputation measurement to create value: an analysis and integration of existing measures. Journal of General Management 32, 112.

Money, K., Hillenbrand, C. and Da Camara, N. (2009) Putting positive pscychology to work in organizations. Journal of General Management 34(3), 21-36.

Money, K., Hillenbrand, C., Henseler, J. and da Camara, N. (2012a) Exploring unanticipated consequences of strategy amongst stakeholder segments: the case of a European revenue service. Long Range Planning 45(5), 395-423.

Money, K., Hillenbrand, C., Hunter, I. and Money, A. G. (2012b) Modelling bi-directional research: a fresh approach to stakeholder theory. Journal of Strategy and Management 5(1), 5-24.

Money, K., Pain, S. and Hillenbrand, C. (2016) Extending the better balance model: how psychology could help to solve the problem of sustainability. Henley Discussion Paper series JMC-2016-01. Henley Business School, University of Reading. 
Morgan, R. M. and Hunt, S. D. (1994) The commitment-trust theory of relationship marketing. Journal of Marketing 58, 20-38.

Neville, B., Bell, S. and Menguc, B. (2005) Corporate reputation, stakeholders and the social performance-financial performance relationship. European Journal of Marketing 39(9/10), 1184-1198.

Newburry, W. (2010) Reputation and supportive behavior: moderating impacts of foreignness, industry and local exposure. Corporate Reputation Review 12(4), 388405.

Nowak, L. I. and Washburn, J. H. (2000) Marketing alliances between non-profits and businesses: changing the public's attitudes and intentions towards the cause. Journal of Nonprofit and Public Sector Marketing 7(4), 33-44.

O’Hair, D., Friedrich, G. W., Wiemann, J. M. and Wiemann, M. O. (1995) Competent Communication. New York: St. Martin's Press.

Oliver, C. (1997) Sustainable competitive advantage: combining institutional and resourcebased views. Strategic Management Journal 18(9), 697-713.

Pain, S. (2017) The age of good. Blog.

Parent, M. M. and Deephouse, D. L. (2007) A case study of stakeholder identification and prioritization by managers. Journal of Business Ethics 75(1), 1-23.

Peloza, J. and Papania, L. (2008) The missing link between corporate social responsibility and financial performance: stakeholder salience and identification. Corporate Reputation Review 11(2), 169-181. 
Pessoa, L. (2013) The Cognitive-Emotional Brain: From Interactions to Integration. MIT Press.

Petrick, J. A., Scherer, R. F., Brodzinski, J. D., Quinn, J. F. and Ainina, M. F. (1999) Global leadership skills and reputational capital: intangible resources for sustainable competitive advantage. Academy of Management Executive 13(1), 58-69.

Ponzi, L. J., Fombrun, C. J. and Gardberg, N. A. (2011) RepTrak ${ }^{\mathrm{TM}}$ Pulse: conceptualizing and validating a short-form measure of corporate reputation. Corporate Reputation Review 14(1), 15-35.

Post, J. E. and Griffin, J. J. (1997) Part vii: Managing reputation: Pursuing everyday excellence: corporate reputation and external affairs management. Corporate Reputation Review 1(2), 165-171.

Pruzan, P. (2001) Corporate reputation: image and identity. Corporate Reputation Review $4(1), 50-64$.

Rao, H. (1994) The social construction of reputation: certification contests, legitimation, and the survival of organizations in the American automobile industry: 1895-1912. Strategic Management Journal 15(1), 29-44.

Ravasi, D. (2002) Analyzing reputation in a cross-national setting. Corporate Reputation Review 4(4), 354-361.

Ravasi, D. (2016) Organizational identity, culture, and image. In: M. G. Pratt, M. Schultz, B. E. Ashforth and D. Ravasi (eds.) The Oxford Handbook of Corporate Reputation. Oxford: Oxford University Press. 
Ravasi, D. and Canato, A. (2013) How do I know who you think you are? A review of research methods on organizational identity. International Journal of Management Reviews 15(2), 185-204.

Remke, R. (2013) Corporate reputation and the discipline of organizational communication. In: Carroll, G. (ed.) The Handbook of Communication and Corporate Reputation. Chichester, UK: Wiley-Blackwell.

Riahi-Belkaoui, A. and Pavlik, E. (1991) Asset management performance and reputation building for large US firms. British Journal of Management 2(4), 231-238.

Rindova, V. P., Williamson, I. O., Petkova, A. P. and Sever, J. M. (2005) Being good or being known: an empirical examination of the dimensions, antecedents, and consequences of organizational reputation. Academy of Management Journal 48(6), 1033-1049.

Roberts, P. W. and Dowling, G. R. (1997) The value of a firm's corporate reputation: how reputation helps attain and sustain superior profitability. Corporate Reputation Review 1(1), 72-76.

Roberts, P. W. and Dowling, G. R. (2002) Corporate reputation and sustained superior financial performance. Strategic Management Journal 23(12), 1077-1093.

Sabate, J. and Puente, E. (2003) Empirical analysis of the relationship between corporate reputation and financial performance: a survey of the literature. Corporate Reputation Review 6(2), 161-177.

Saraeva, A. (2017) The interactions between messages and stakeholder (dis)identification with messengers: exploring their moderating impact on the links between 
perceptions of corporate reputation, organisational (dis)identification, and behavioural outcomes. PhD thesis, University of Reading, UK.

Scherer, A. G. and Palazzo, G. (2011) The new political role of business in a globalized world: a review of a new perspective on CSR and its implications for the firm, governance, and democracy. Journal of Management Studies 48(4), 899-931.

Sen, S. and Bhattacharya, C. (2001) Does doing good always lead to doing better? Consumer reactions to corporate social responsibility. Journal of Marketing Research 38(2), $225-243$.

Shamma, H. M. and Hassan, S. S. (2009) Customer and non-customer perspectives for examining corporate reputation. Journal of Product and Brand Management 18(5), $326-337$.

Shamsie, J. (2003) The context of dominance: an industry-driven framework for exploiting reputation. Strategic Management Journal 24(3), 199-215.

Shapiro, C. (1982) Consumer information, product quality, and seller reputation. Bell Journal of Economics 13(1), 20-35.

Shapiro, C. (1983) Premiums for high quality products as returns to reputations. Quarterly Journal of Economics 98(4), 659-679.

Shrum, W. and Wuthnow, R. (1988) Reputational status of organizations in technical systems. American Journal of Sociology 93(4), 882-912.

Sjovall, A. M. and Talk, A. C. (2004) From actions to impressions:cognitive attribution theory and the formation of corporate reputation. Corporate Reputation Review 7(3), 269281. 
Sobol, M. G. and Farrelly, G. (1988) Corporate reputation: a function of relative size or financial performance? Review of Financial Economics 24(1), 45.

Srivoravilai, N., Melewar, T. C., Liu, M. J. and Yannopoulou, N. (2011) Value marketing through corporate reputation: an empirical investigation of Thai hospitals. Journal of Marketing Management 27(3/4), 243-268.

Stanaland, A., Lwin, M. and Murphy, P. (2011) Consumer perceptions of the antecedents and consequences of corporate social responsibility. Journal of Business Ethics 102(1), 47-55.

Staw, B. M. and Epstein, L. D. (2000) What bandwagons bring: effects of popular management techniques on corporate performance, reputation, and CEO pay. Administrative Science Quarterly 45(3), 523-556.

Suchman, M. C. (1995) Managing legitimacy: strategic and institutional approaches. Academy of management Review 20(3), 571-610.

Turban, D. B. and Greening, D. W. (1997) Corporate social performance and organizational attractiveness to prospective employees. Academy of Management Journal 40(3), $658-672$.

Unsworth, K. L., Dmitrieva, A. and Adriasola, E. (2013) Changing behaviour: Increasing the effectiveness of workplace interventions in creating pro-environmental behaviour change. Journal of Organizational Behavior 34(2), 211-229.

van Riel, C. B. M. (2002) Top of mind awareness of corporate brands among the Dutch public. Corporate Reputation Review 4(4), 362-373. 
Vecino-Ortiz, A. I., Bishai, D., Chandran, A. et al (2014) Seatbelt wearing rates in middle income countries: a cross-country analysis. Accident Analysis \& Prevention 71, 115119.

Vendel $\varnothing$, M. T. (1998) Narrating corporate reputation: becoming legitimate through storytelling. International Studies of Management and Organization 28(3), 120-137.

Waddock, S. (2000) The multiple bottom lines of corporate citizenship: social investing, reputation, and responsibility audits. Business and Society Review 105(3), 323-345.

Walker, K. (2010) A systematic review of the corporate reputation literature: definition, measurement, and theory. Corporate Reputation Review 12(4), 357-387.

Walsh, G., Albrecht, A. K., Kunz, W. and Hofacker, C. F. (2016) Relationship between online retailers' reputation and product returns. British Journal of Management 27(1), 320.

Walsh, G., Albrecht, A. K., Hofacker, C. F., Grant, I. and Takahashi, I. (2016) Developing and validating a scale of consumer brand embarrassment tendencies. Journal of Business Research 69(3), 1138-1147.

Walsh, G. and Beatty, S. E. (2007) Customer-based corporate reputation of a service firm: scale development and validation. Journal of the Academy of Marketing Science 35(1), 127-143.

Walsh, G. and Wiedmann, K.-P. (2004) A conceptualization of corporate reputation in Germany: an evaluation and extension of the RQ. Corporate Reputation Review 6(4), 304-312. 
Walsh, G., Dinnie, K. and Wiedmann, K.-P. (2006) How do corporate reputation and customer satisfaction impact customer defection? A study of private energy customers in Germany. Journal of Services Marketing 20(6), 412-420.

Walsh, G., Beatty, S. E. and Shiu, E. M. K. (2009a) The customer-based corporate reputation scale: replication and short form. Journal of Business Research 62(10), 924-930.

Walsh, G., Mitchell, V.-W., Jackson, P. R. and Beatty, S. E. (2009b) Examining the antecedents and consequences of corporate reputation: a customer perspective. British Journal of Management 20(2), 187-203.

Walsh, G., Schaarschmidt, M. and Ivens, S. (2017) Effects of customer-based corporate reputation on perceived risk and relational outcomes: empirical evidence from gender moderation in fashion retailing. Journal of Product and Brand Management 26(3), 227-238.

Wang, C.-Y. (2009) Investigating antecedents of consumers' recommend intentions and the moderating effect of switching barriers. Service Industries Journal 29(9), 1231-1241.

Wang, Y. and Berens, G. (2015) The impact of four types of corporate social performance on reputation and financial performance. Journal of Business Ethics 131(2), 337-359.

Wartick, S. L. (1992) The relationship between intense media exposure and change in corporate reputation. Business and Society Review 31(1), 33-49.

Weaver, P. H. (1988) The Suicidal Corporation: How Big Business Fails America. New York: Cato Institute.

Weed, K. (2017) Unilever CMO. Presentation at Cannes, June 2017. 
Weigelt, K. and Camerer, C. (1988) Reputation and corporate strategy: a review of recent theory and application. Strategic Management Journal 9(5), 443-454.

West, B., Hillenbrand, C. and Money, K. (2014) Building employee relationships through corporate social responsibility the moderating role of social cynicism and reward for application. Group and Organization Management 40(3), 295-322.

West, B., Hillenbrand, C., Money, K., Ghobadian, A. and Ireland, R. D. (2015) Exploring the impact of social axioms on firm reputation: a stakeholder perspective. British Journal of Management 27(2), 249-270.

Whetten, D., Foreman, P. and Dyer, W. G. (2014) Organizational identity and family business. In: Melin, L., Nordqvist, M. and Sharma, P. (eds.) SAGE Handbook of Family Business. Sage.

Whetten, D. A. and Mackey, A. A. (2002) A social actor conception of organizational identity and its implications for the study of organizational reputation. Business and Society 41(4), 393-414.

Wiedmann, K. and Prauschke, C. (2005) Intangible assets and corporate reputation: conceptual relationships and implications for corporate practice. Paper presented at the Reputation Institute Conference, Madrid, Spain 2005.

Wiedmann, K.-P. (2002) Analyzing the German corporate reputation landscape. Corporate Reputation Review 4(4), 337-353.

Wiedmann, K.-P. and Buxel, H. (2005) Corporate reputation management in Germany: results of an empirical study. Corporate Reputation Review 8(2), 145-163. 
Woodward, J. L. and Roper, E. (1951) The effective public for plant-community public relations effort. Public Opinion Quarterly 15(4), 624-634.

Wulf, K. D., Odekerken-Schröder, G. and lacobucci, D. (2001) Investments in consumer relationships: a cross-country and cross-industry exploration. Journal of Marketing 65(4), 33-50.

Yang, S.-U. and Grunig, J. E. (2005) Decomposing organisational reputation: the effects of organisation-public relationship outcomes on cognitive representations of organisations and evaluations of organisational performance. Journal of Communication Management 9(4), 305-325.

Yoon, E., Guffey, H. and Kijewski, V. (1993) The effects of information and company reputation on intentions to buy a business service. Journal of Business Research $27(3), 215-228$.

Zattoni, A. and Ravasi, D. (2000) Grandi Imprese E Grandi Gruppi in Italia: Assetto Proprietario E Performance [Italian big firms and groups: ownership and performance assets]. Economia and Management, 2, 55-72.

Zyglidopoulos, S. and Phillips, N. (1999) Responding to reputational crises: a stakeholder perspective. Corporate Reputation Review 2(4), 333-350. 
Table 1. Review of the CR literature in time periods 1940-1990, 1990-2006, 2006-2017(present)

\begin{tabular}{|c|c|c|c|}
\hline $\begin{array}{l}\text { Time } \\
\text { period }\end{array}$ & Key themes & Key studies & Example studies \\
\hline \multirow{3}{*}{$\begin{array}{l}1940- \\
1990\end{array}$} & $\begin{array}{l}\text { 1. CR as strategic } \\
\text { asset }\end{array}$ & $\begin{array}{l}\text { CR as strategic asset, often linked to financial } \\
\text { performance } \\
\text { e.g. Cave and Porter, 1977; Freeman, 1984; Sobol } \\
\text { and Farrelly, 1988; Weigelt and Camerer, 1988; } \\
\text { Dutton and Dukerich, } 1991\end{array}$ & $\begin{array}{l}\text { Sobol and Farrelly (1988) explore to what extent CR attributes are } \\
\text { driven by past financial performance, and discuss whether and how } \\
\text { good financial performance may reflect good CR. } \\
\text { Weigelt and Camerer (1988) provide theoretical and empirical } \\
\text { evidence on the effects of CR on strategic development, which } \\
\text { leads to generating future rents. }\end{array}$ \\
\hline & 2. CR as signal & $\begin{array}{l}\text { CR as signals managed by the firm } \\
\text { e.g. Kreps and Wilson, 1982; Shapiro, 1983; } \\
\text { Milgrom and Roberts, 1986; Fombrun and Shanley, } \\
\text { 1990; Raihi-Belkaoui and Pavlik, 1991; Bagwell, } \\
1992\end{array}$ & $\begin{array}{l}\text { Shapiro (1983) examines the role of CR in a competitive } \\
\text { environment; the study suggests CR as a mechanism that signals } \\
\text { quality assurance. } \\
\text { Raihi-Belkaoui and Pavlik (1991) support the notion that CR is } \\
\text { largely driven by information about corporate asset management } \\
\text { performance via market and accounting signalling. }\end{array}$ \\
\hline & $\begin{array}{l}\text { 3. Company- } \\
\text { centric view of } C R\end{array}$ & $\begin{array}{l}\text { CR and related constructs (such as image) studied } \\
\text { from the perspective of the company } \\
\text { e.g. Barlow and Payne, 1949; Woodward and Roper, } \\
\text { 1951; Bolger, 1959; Macleod, 1967; Dowling, 1986; } \\
\text { Sobol and Farrelly, 1988; McGuire et al, } 1990\end{array}$ & $\begin{array}{l}\text { Barlow and Payne (1949) provide one of the first empirical } \\
\text { evidence on the effects of familiarity, knowledge and CR-related } \\
\text { attitudes. } \\
\text { Bolger (1959) develops an innovative approach to measure CR - } \\
\text { 'company image profile' - which helps to systematically evaluate a } \\
\text { focal company's CR, the CRs of its competitors and the CR } \\
\text { stakeholders expect from the company. }\end{array}$ \\
\hline $\begin{array}{l}1990- \\
2006\end{array}$ & $\begin{array}{l}\text { 1. CR as } \\
\text { perception }\end{array}$ & $\begin{array}{l}\text { CR as perception } \\
\text { e.g. Wartick,1992; Fombrun, 1996; Post and Griffin, } \\
\text { 1997; Balmer, 1998; Chematony, 1999; Bennett and } \\
\text { Kottasz, 2000; Mahon and Wartick, 2002; Roberts }\end{array}$ & $\begin{array}{l}\text { Wartick (1992) is one of the first researchers to provide an explicit } \\
\text { attention to CR; he also provides a definition of CR emphasising the } \\
\text { perceptual nature of the construct. }\end{array}$ \\
\hline
\end{tabular}




\begin{tabular}{|c|c|c|}
\hline & $\begin{array}{l}\text { and Dowling, 2002; Argenti and Druckenmiller, } \\
2004\end{array}$ & $\begin{array}{l}\text { Fombrun (1996) offers a review of CR research and practical } \\
\text { implications; develops one of most cited definitions of CR. }\end{array}$ \\
\hline $\begin{array}{l}\text { 2. Distinguishing } \\
\text { between image, } \\
\text { identity and CR }\end{array}$ & $\begin{array}{l}\text { Definition of CR and related constructs } \\
\text { e.g. Dutton and Duckerich, 1991; Balmer, 1998; } \\
\text { Pruzan, 2001; Whetten and Mackey, 2002; Balmer } \\
\text { and Frasey, 2003; Fillis, 2003; Brown et al, 2006; } \\
\text { Illia and Lurati, } 2006\end{array}$ & $\begin{array}{l}\text { Balmer (1998) is one of first UK academics focusing on CR; } \\
\text { developing a model, distinguishing corporate image and CR. } \\
\text { Brown et al (2006) draw essential clarification to the ongoing } \\
\text { debate on the links between the related constructs of CR, identity } \\
\text { and image. }\end{array}$ \\
\hline $\begin{array}{l}\text { 3. Development } \\
\text { and critique of } C R \\
\text { measures }\end{array}$ & $\begin{array}{l}\text { Measures of CR and critique of measures } \\
\text { e.g. Fryxell and Wang, 1994; Fombrun et al, 2000; } \\
\text { Davies et al, 2001; Macmillan et al, 2004; Walsh et } \\
\text { al, } 2007\end{array}$ & $\begin{array}{l}\text { Fryxell and Wang (1994) suggest that the Fortune ranking is largely } \\
\text { driven by financial performance, and hence a financially based way } \\
\text { of measuring CR. } \\
\text { Authors such as Fombrun (2000), Davies et al (2005), MacMillan et } \\
\text { al (2004); and Walsh et al }(2007,2009,2014) \text { propose perception- } \\
\text { based measurement tools for CR. }\end{array}$ \\
\hline $\begin{array}{l}\text { 4. Placing CR } \\
\text { within a causal } \\
\text { framework (i.e. } \\
\text { study of causes } \\
\text { and outcomes) }\end{array}$ & $\begin{array}{l}\text { Placing CR in causal framework analysis } \\
\text { e.g. Dutton et al,1994; Brown, 1998; Gardberg and } \\
\text { Fombrun, 2002; Ahearne et al, 2005; Rindova et al, } \\
\text { 2005; Wiedmann and Prauschke, 2005; Money and } \\
\text { Hillenbrand, } 2006\end{array}$ & $\begin{array}{l}\text { Rindova et al (2005) provide theoretical and empirical evidence } \\
\text { within a causal model of how stakeholder perceptions affect } \\
\text { economic (corporate) outcomes. } \\
\text { Money and Hillenbrand (2006) offer a reconciliation of the two } \\
\text { opposing views on CR (company vs stakeholder oriented); the study } \\
\text { integrates models and frameworks that focus on CR as a perceptual } \\
\text { and attitudinal construct within a framework of strategic thinking. }\end{array}$ \\
\hline $\begin{array}{l}\text { 5. Stakeholder- } \\
\text { centric view of } C R\end{array}$ & $\begin{array}{l}\text { Stakeholder studies } \\
\text { e.g. Mael and Ashforth, 1992; Zyglidopoulos and } \\
\text { Phillips, 1999; Sen and Bhattacharya, 2001; } \\
\text { Waddock, 2002; Ahearne et al, 2005; MacMillan et } \\
\text { al, 2005; Caruana et al, 2006; Walsh et al, 2006; } \\
\text { Freeman, } 2010\end{array}$ & $\begin{array}{l}\text { Mael and Ashforth (1992) provide empirical evidence on how and } \\
\text { why CR (i.e. prestige) may impact stakeholders' affiliations with } \\
\text { organisations (i.e. organisational identification) and, in turn, lead to } \\
\text { stakeholders' behavioural outcomes. } \\
\text { MacMillan et al (2005) place CR within stakeholder-company } \\
\text { relationships, emphasising mutual exchange and influence between } \\
\text { both parties. }\end{array}$ \\
\hline
\end{tabular}




\begin{tabular}{|c|c|c|c|}
\hline \multirow[t]{2}{*}{$\begin{array}{l}\text { 2006- } \\
\text { present }\end{array}$} & $\begin{array}{l}\text { 1. Linking CR to } \\
\text { management } \\
\text { theories }\end{array}$ & $\begin{array}{l}\text { From a strategic/asset-based perspective, CR is } \\
\text { linked, for example to: resource-based theory (see } \\
\text { Deephouse, 2000; Roberts and Dowling, 2002; } \\
\text { Shamsie, 2003; Carmeli and Tishler, 2004; Carter } \\
\text { and Ruefli, 2006; Bergh et al, 2010; Boyd et al, } \\
\text { 2010); institutional theory (see Rao, 1994; Staw } \\
\text { and Epstein, 2000; Deephouse and Carter, 2005; } \\
\text { Srivoravilai et al, 2011; Foreman et al, 2012; Davies } \\
\text { and Chun, 2015; Davies and Olmedo-Cifuentis 2016; } \\
\text { Deephouse et al, 2016); signalling theory (see } \\
\text { Basdeo et al, 2006; Newburry, 2010; Gardberg et al, } \\
\text { 2015; Walsh et al, 2015; 2017; Gardberg et al, } \\
\text { 2017); and non-market strategy (see Mahon and } \\
\text { Wartick, 2003; Ghobadian et al, 2015; Leidong et al, } \\
\text { 2015) } \\
\text { From a relational/perception-based perspective, } \\
\text { CR is linked, for example, to: stakeholder theory } \\
\text { (see Bhattacharya et al, 2008; Freeman, 2010; } \\
\text { Wang and Berens, 2015); social identity theory (see } \\
\text { Korschun, 2015); attribution theory (see Helm, } \\
\text { 2013); and relationship theories (see Money et al, } \\
\text { 2012; Korschun et al, 2014). }\end{array}$ & $\begin{array}{l}\text { Carroll (2010) brings agenda-setting theory to CR literature and } \\
\text { studies the impact of media on CR development (see also Kiousis et } \\
\text { al, 2007; Besiou et al, 2013; Bantimaroudis and Zyglidopoulos, } \\
\text { 2014; Lee et al, 2015). } \\
\text { Dowling and Moran (2012) follow a strategic view and argue that } \\
\text { only when CR is grounded in corporate strategy, may companies } \\
\text { achieve a significant competitive advantage; to support that the } \\
\text { authors offer a framework that unpacks strategy-led approaches to } \\
\text { CR (see also Deephouse and Carter, 2005; Basdeo et al, 2006). } \\
\text { Helm (2013) utilises attribution theory to understand how } \\
\text { cognitive processes drive stakeholders satisfaction and intention } \\
\text { (see also Sjovall and Talk, 2004; Love and Kraatz, 2009; 2017; } \\
\text { Mishina et al, 2012). } \\
\text { Korschun (2015) draws on social identity theory to explore } \\
\text { psychological contributors to stakeholder relationships (see also } \\
\text { Helm, 2011, 2012; Ashforth et al, 2013; Korschun and Du, 2013; } \\
\text { Beatty et al, 2016). }\end{array}$ \\
\hline & $\begin{array}{l}\text { 2. Understanding } \\
\text { underlying } \\
\text { mechanisms of } \\
\text { how CR develops }\end{array}$ & $\begin{array}{l}\text { Exploring a broader set of drivers and outcomes of } \\
\text { CR } \\
\text { e.g. Walsh et al, 2007, 2009; Hillenbrand et al, } \\
\text { 2011; Lange et al, 2011; Ponzi et al, 2011; Fombrun, } \\
\text { 2012; Fombrun et al, 2015; Walsh et al, } 2015\end{array}$ & $\begin{array}{l}\text { Hillenbrand et al (2011) unpack underlying psychological processes } \\
\text { that drive stakeholders' behavioural responses to perceptions of } \\
\text { CRs. } \\
\text { Fombrun et al (2015) offers an extensive model of CR dimensions - } \\
\text { RepTrak }^{\circledR} \text { - which has been widely applied to cross-company, } \\
\text { industry, city and country studies. }\end{array}$ \\
\hline
\end{tabular}




\begin{tabular}{|l|l|l|l|}
\hline $\begin{array}{l}\text { 3. Understanding } \\
\text { contingency and } \\
\text { moderators in CR } \\
\text { research }\end{array}$ & $\begin{array}{l}\text { Understanding contingencies and moderators of } \\
\text { CR, for example, social axioms, culture, } \\
\text { identification, social media, influencers } \\
\text { e.g. Kreiner and Ashforth, 2004; Money and } \\
\text { Hillenbrand, 2006; Ashforth et al, 2008; } \\
\text { Bhattacharya et al, 2008; Korschun, 2015; West et } \\
\text { al, 2014, 2015; Walsh et al, 2015 }\end{array}$ & $\begin{array}{l}\text { West } \text { et anpack how underlying psychological } \\
\text { mechanisms, i.e. social axioms or deeply held individual beliefs, } \\
\text { moderate perceptions of CR as well as outcome behaviours. } \\
\text { Walsh et al (2016) unpack psychological differences in } \\
\text { embarrassment tendency among stakeholders (i.e. individuals' } \\
\text { proneness to feel embarrassed) in relation to different companies } \\
\text { (i.e. brands). }\end{array}$ \\
\hline
\end{tabular}


Figure 1. Causal framework of CR by Money and Hillenbrand (2006), built on Rindova et al (2005) and Walsh and Wiedmann (2004)

\section{Anteced ents $\Rightarrow$ Corporate Reputation $\Rightarrow$ Consequences}

\begin{tabular}{|c|c|c|c|c|c|c|}
\hline Strategic level & Asset Ges & nerating Activities & Intangible & Assets & $\begin{array}{l}\text { Market } \\
\text { Perfor }\end{array}$ & $\begin{array}{l}\text { sets / } \\
\text { ince }\end{array}$ \\
\hline $\begin{array}{c}\text { Fombres (1996) } \\
\text { Reputation Quotient } \\
\text { (R Q) }\end{array}$ & & & 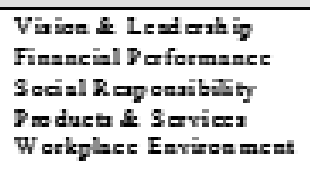 & $\begin{array}{l}\text { Emetional } \\
A_{D D}=1\end{array}$ & & \\
\hline $\begin{array}{c}\text { Davies (2003) } \\
\text { Corporate Persous lity } \\
\text { Scale }\end{array}$ & & & $\begin{array}{l}\text { Jud gement of the } \\
\text { gerranaliy of an } \\
\text { otganation }\end{array}$ & 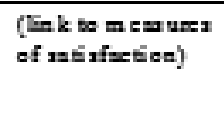 & 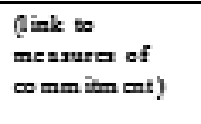 & \\
\hline $\begin{array}{c}\text { Bereas \& V V } 2 \text { Riol } \\
\text { (2004) } \\
\text { Strenm s of Th ought in } \\
\text { Reputation L iters ture }\end{array}$ & & $\begin{array}{l}\text { Activitiex amociated with } \\
\text { the develogm ent of trust } \\
\text { (implied) }\end{array}$ & 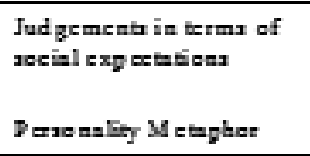 & Trust & & \\
\hline $\begin{array}{c}\text { Waluh \& Wiedmann } \\
\text { (2004) } \\
\text { Extension of the RQ } \\
\text { in Germany }\end{array}$ & & 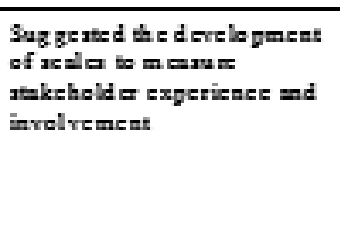 & 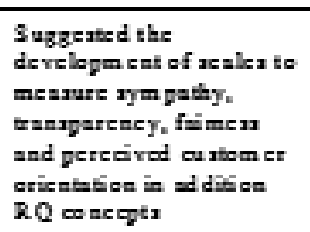 & $\begin{array}{l}\text { Suggerted the } \\
\text { develoyment of } \\
\text { acalex to } \\
\text { meaure truat } \\
\text { and natiffaction }\end{array}$ & 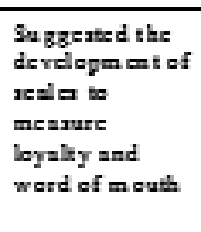 & \\
\hline $\begin{array}{l}\text { MacMillim of al_. (2004) } \\
\text { SPIRIT }\end{array}$ & $\begin{array}{l}\text { Outride } \\
\text { Influeneex } \\
\text { (What he } \\
\text { mediand } \\
\text { grexure } \\
\text { groupd nay) }\end{array}$ & 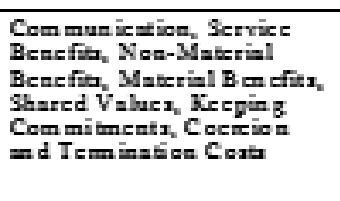 & & 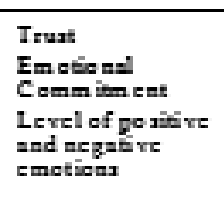 & $\begin{array}{l}\text { Advocacy } \\
\text { Cospunation } \\
\text { Extenxien } \\
\text { Retertien } \\
\text { Subverien }\end{array}$ & \\
\hline Personal level & Obutrution & Exptrit nst & 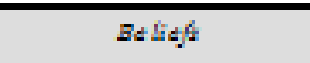 & 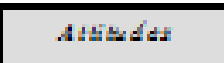 & Intentions & Botkevieurn \\
\hline
\end{tabular}


Figure 2. Novel reputation framework

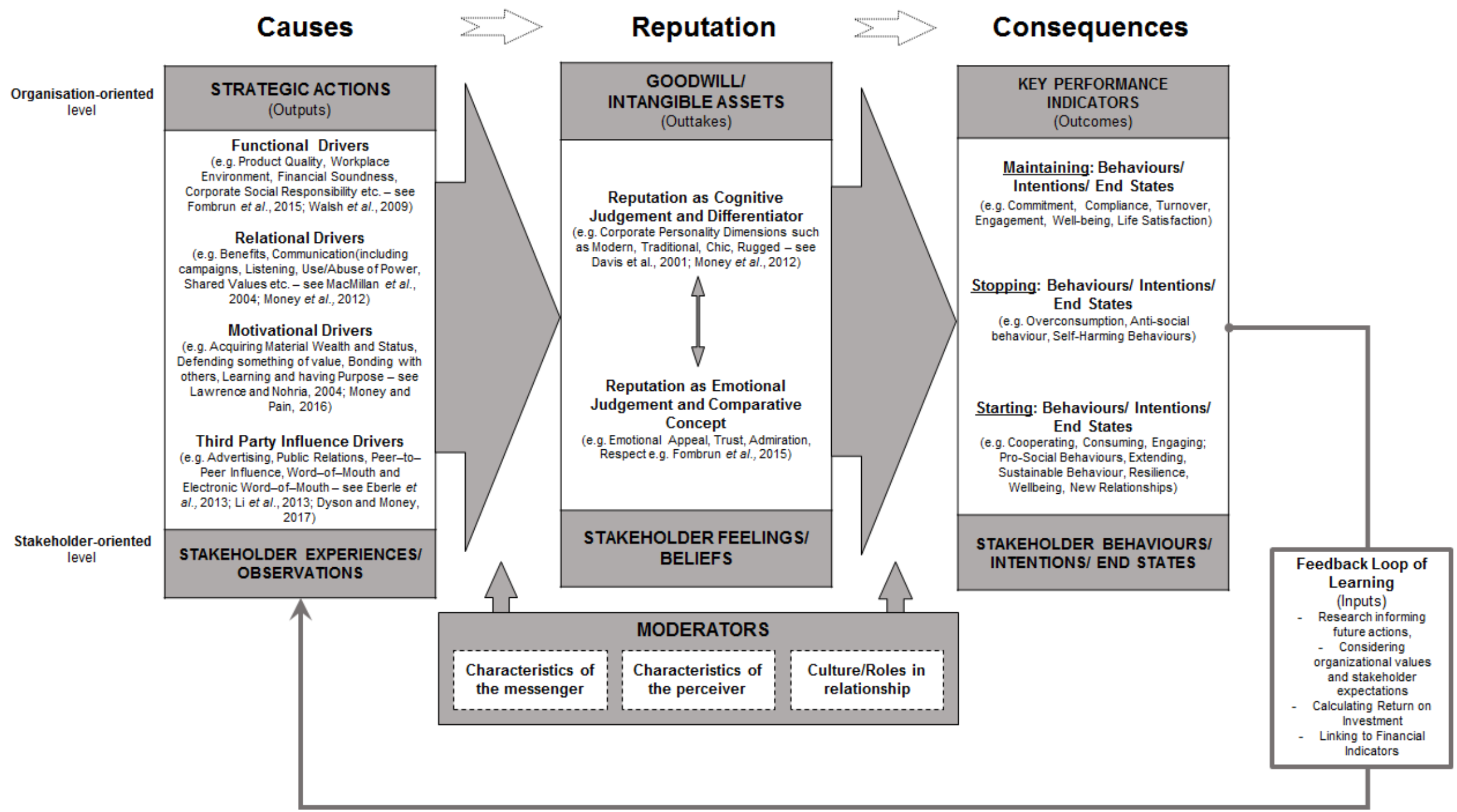

